\title{
Sonic Grounding and Internalizing Structure: Themes of Continuity in the Music of John Coltrane
}

\author{
Jason Squinobal
}

Examining the musical development of John Coltrane, one often gets a deep sense of change. Respected Coltrane scholar Lewis Porter characterizes Coltrane's career by the "fact that he was constantly developing and changing." ${ }^{1}$ To account for this perception of change, the tendency is to divide Coltrane's music into segmented stylistic periods. This allows us a greater understanding of Coltrane's developmental building blocks, and the specific elements that he focused on while creating his music. For example, Eric Nisenson divides Coltrane's work into "Early Coltrane" including his work with Dizzy Gillespie, Miles Davis, and his first recordings for Atlantic, a "Middle Period" including his work with Thelonious Monk and the early Impulse recordings, and finally a "Late Period" including Coltrane's avant-garde albums. ${ }^{2}$ In The Dawn of Indian Music in the West Peter Lavezzoli states "Coltrane's music went through more evolutionary stages during his ten years as a solo recording artist than many musicians realize in a fuller lifetime." ${ }^{3}$ Historical and bibliographical references including the New Grove Dictionary of Music and Musicians also characterized Coltrane's development as moving from one period to the next. ${ }^{4}$

Similarly, in his instructional book for saxophonists, The Jazz Style of John Coltrane (1980), David Baker divides Coltrane's work into a "change running period," a "modal period," and an "experimental period," describing some of the improvisational techniques used in each. ${ }^{5}$ Baker's book uses different periods to make Coltrane's techniques easier to understand. This is the norm for books focused on analyzing Coltrane's musical style. For example, Carl Coan's John Coltrane Solos and Ronny Schiffs Coltrane Plays Standards both divide their

${ }^{1}$ Lewis Porter, John Coltrane: His Life and Music. (Ann Arbor: University of Michigan Press, 1998), $x$.

${ }^{2}$ Eric Nisenson, Ascension: John Coltrane and His Quest, (New York: St Martins Press, 1993).

${ }^{3}$ Peter Lavezzoli, The Dawn of Indian Music in the West (New York: Continuum, 2007) 289.

${ }^{4}$ Barry Kernfeld, et al. "Coltrane." The New Grove Dictionary of Jazz, 2nd ed.. (Grove Music Online. Oxford Music Online. Oxford University Press, accessed March 14, 2014, http://www.oxfordmusiconline.com/subscriber/article/grove/music/J541800pg1.)

${ }^{5}$ David Baker, The Jazz Style of John Coltrane, (Lebanon, IN: Studio 224, 1980). 
solo transcriptions into groups based on the accepted periodization of Coltrane. ${ }^{6}$ However, while focusing on the specifics and dividing Coltrane's music into segmented parts, we risk loosing the sense of unity and continuity, the wholeness present in Coltrane's music, and the fluid nature with which he progressed. Segmented periodization also separates Coltrane's final recordings and performances, generally beginning after $A$ Love Supreme, from everything that came before. This artificial split between "early" and "late" Coltrane makes his final recordings less accessible and more difficult to appreciate. The listener loses identifiable points of reference that, in earlier recordings/performances, were easier to identify.

I perceive Coltrane's music in its entirety as a whole that is greater then the sum of its separated parts. I view his musical development as a unified whole. From his very first musical influences to the end of his life, Coltrane traveled through a single musical continuum not separated by stages or periods that were isolated and complete in and of themselves. The continuity of a single unified style throughout Coltrane's career provides reference points, drawn from his earlier years, and present in his final years of music making, which anchor the listener and grant a deeper understanding of the goals and accomplishments Coltrane made throughout his musical career.

\section{SONIC GROUNDING: THEORETICAL FRAMEWORK}

If the continuity of Coltrane's development can be effectively represented as one fluid continuum, then there must be at least one concept or theme found throughout his music. The primary theme present throughout Coltrane's music is his unrelenting, obsessive drive to master and overcome the restrictive structural elements of jazz: harmonic progression, cyclical form, and metered rhythm. While this statement is hardly profound, it is through an understanding how Coltrane accomplished the mastery of his medium that we can begin to see the unity and fluidity of his musical style. It is tempting to divide Coltrane's development into the mastery of the three above structural elements; however, his mastery over each is dependent on his mastery over the others. By mastering harmonic progression, Coltrane acquired tonal freedom and incorporated chromaticism into his solo performances. Without the restrictions of harmonic progressions, cyclical formal structure was no longer necessary. In the attempt to master harmonic and formal structure, Coltrane uses the groove or metered rhythm as a point of reference, an anchor, something for him to hold onto while

${ }^{6}$ Carl Coan, John Coltrane Solos, (Milwaukee, WI: Hal Leonard, 1995); Ronny Schiff, Coltrane Plays Standards, Milwaukee, (WI: Hal Leonard, 2000). 
exploring harmonic and formal structure. However, when harmonic and formal structure are removed metered rhythm becomes constrictive instead of constructive. The groove becomes unnecessarily confining and incongruous with the freedoms found in the absence of harmony and form. Therefore, Coltrane removes this restrictive feature as well.

Coltrane worked relentlessly to master the concepts and techniques of jazz improvisation and the saxophone, and it is because it did not come easy to him that he was so successful. Coltrane was an artist; yet, he honed the skills of his art with the rigor of a musical scientist. Drummer Elvin Jones used the same metaphor to describe his own musical process in an interview with Frank Kofsky; Jones responds to a question about musical style by stating:

I'm trying to find through the process of elimination, I suppose, like any scientist would try to work on a project, what is right and what is wrong and try to-musically, you have to make up your mind and you don't have time to wait for the results. You experiment and do it right away, make your selection, and it's almost immediate or simultaneous with the other things that are going on...

When questioned about the scientific aspirations of his approach Jones went on to state that music, religion and just about everything else in life was a science and should be treated accordingly. I believe this statement characterizes Coltrane's approach to music as well.

Like a scientist in his laboratory, Coltrane used his performances on stage and in the recording studio to experiment, develop theories, skills, and techniques, and to decide what worked and what did not work. In his pursuit to master his medium, Coltrane used the technique of isolation and restriction to explore and experiment with the musical materials he was working on. The techniques of isolation and restriction create what I term Sonic Grounding; sonic meaning the aural occurrence or characteristic sound element and grounding, meaning a restricted point of reference. The process of sonic grounding provides Coltrane with a constant in his musical experiments, something to anchor him in his explorations. Audiences can also use sonic grounding as a point of reference to mitigate the dissonance that often occurred in Coltrane's music due to his investigative nature. It is though the process of sonic grounding that we are able to trace a thread of unity and fluidity through Coltrane's music; and it is through the techniques of isolation and restriction that we can identify the elements of

\footnotetext{
${ }^{7}$ Frank Kofsky, "Elvin Jones Part III: an Interview with Elvin Jones," Journal of Jazz Studies Vol.
} 5 N1 Fall/Winter 1978. (88) 
sonic grounding. It is no surprise that as Coltrane develops a mastery over his artistic medium, his restrictions and points of reference become increasingly tenuous, thus providing ever-increasing freedom to his musical explorations and an ever-increasing challenge to his audiences to hold onto any identifiable point of reference with which to orient themselves.

My understanding of sonic grounding ultimately stems from the time I spent studying improvisation with Jerry Bergonzi and George Garzone. Both are wellknown, jazz educators and pedagogues who have very distinctive styles of performing and teaching. After many years of studying concepts I learned from each of them, I realized that many of their lessons taught similar concepts from different perspectives. I do not believe that either Bergoinzi or Garzone used the term sonic grounding, but much of what I learned from them both dealt with this concept. I have come to understand Garzone's chromatic triadic concept from this perspective: that the sonic power, or gravity of the triad, particularly the major, and to a lessor degree minor triad, has such sonic grounding that the listener's ear accepts the sequential playing of any triad over any harmonic progression, due to the natural sonic strength of the triad. Similarly, Bergonzi's four-note melodic structures derived from pentatonic scales depend on the same principal. Furthermore, I have come to realize that many of Bergonzi's melodic rhythmic concepts, like the 4,5 , or 6 , consecutive eighth note patterns, are based on the principle that the weight of a strong rhythmic structure repeated and manipulated can provide a point of reference for harmonic exploration.

In a similar fashion, Coltrane isolates or restricts his focus on one musical characteristic at a time and relies on the weight, gravity, the sonic grounding of the characteristic to allow him to explore other aspects to their fullest potential. Coltrane uses smooth common tones and linear voice leading, explicitly essential linear harmony, and repetitive rhythmic structures, as basic sonic grounding techniques that allow him to explore and experiment with a variety of concepts. These concepts are mostly harmonic or rhythmic, and they are the most restrictive structural features of jazz improvisation. When Coltrane is exploring and experimenting with an element of jazz improvisation, he isolates it or he restricts the other elements. These restrictions become the foundation, the sonic grounding, and the point of reference so that all of his concentration can be on the element he is exploring. 


\section{CHARLIE PARKER AND BEBOP INFLUENCE}

I am certainly not arguing that Coltrane set out at the beginning to master and overcome the structural limitations of jazz improvisation. However, his desire to master bebop improvisation and the influence of Charlie Parker led to and shaped Coltrane's later experiments and explorations. This initial dedication to mastering bebop began in the mid 1940's, when he moved to Philadelphia, and coincides with his associations with Philadelphia musicians and his deep interest in three dominant musicians of that period; Charlie Parker, Dizzy Gillespie and Colman Hawkins. The modus operandi of jazz musicians in the1940s is important to understanding what Coltrane was trying to accomplish musically throughout his career.

Coltrane's initial influences, particularly the way Parker, Hawkins, and Gillespie interacted with the musical repertoire, never left him. The origins of Coltrane's focus on harmonic structure, the thread that ties all of his musical development together must be attributed to his time practicing with Jimmy Heath and Benny Golson, studying the music of Parker and Hawkins, and performing in Dizzy Gillespie's bands.

Parker, Hawkins, and Gillespie, all had the desire to push the limits of their music, particularly the characteristics associated with technical facility and harmonic structure. ${ }^{8}$ All three musicians:

1. Had a particular penchant for the blues form and altered its harmonic structure significantly.

2. Increased the harmonic density of well-known songs by incorporating chord substitutions that were not commonly used in standard jazz repertoire.

3. Performed standard jazz repertoire at increasingly challenging tempos.

4. Composed or improvised complex and technically challenging melodies over well-known standard jazz forms.

5. Expanded the harmonic language of jazz by incorporating more chromatic melodic material in both their melodies and their improvised solos.

6. Composed original compositions with new harmonic structures utilizing the above-mentioned musical traits

\footnotetext{
${ }^{8}$ For more information regarding Parker, Hawkins, or Gillespie see Carl Woideck, Charlie Parker: His Music and Life, (Ann Arbor, University of Michigan Press, 1998) and Alyn Shipton, Groovin' High: The Life of Dizzy Gillespie. (Cary, NC, USA: Oxford University Press, USA, 2001.)
} 
Coltrane's fluid musical development is dependent on utilizing these six characteristics to master the restrictive nature of harmonic structure. Coltrane never ceases to execute fluid voice leading of dense harmonic progressions, he implements them as substitutions on standard harmonic progressions, he sets them out in original compositions, and he internalizes and implies them over collective improvisation. As his mastery over harmonic structure increases, he transitions from prescribing dense harmonic progressions to utilizing them at will over static harmonic palettes, or freely improvised accompaniments. ${ }^{9}$

Lewis Porter's biography of Coltrane provides us with a wealth of information regarding Coltrane's musical development during this time. Porter's work gives important evidence that shows how much influence local musicians in Philadelphia and his association with Parker, Hawkins, and Gillespie had on Coltrane's musical development. ${ }^{10}$ In his earliest recordings, Porter identifies evidence of Coltrane studying and performing the repertoire of all three musicians. ${ }^{11}$ There are also examples of Coltrane pushing his technical capabilities by improvising at top speeds. Porter characterizes some of Coltrane's earliest work by identifying "awkwardness" in Coltrane's improvised solos "due to his desire to do highly technical things that he is not quite capable of executing." ${ }^{12}$ Porter attributes this desire to the influence bebop musicians like Parker and Gillespie. ${ }^{13}$

There are of course other influences at this time in Coltrane's development. Dexter Gordon, Wardell Grey, Don Byas and Sonny Stitt all play a pivotal roll in helping Coltrane develop his own identifiable voice on the tenor saxophone. ${ }^{14}$ However, I stress a brief point that Porter makes; "Stitt, Gordon, and Wardell Gray, like Coltrane, had absorbed the lessons not only of [Lester] Young, but of Hawkins and Parker. They had already assimilated these lessons into consistent, identifiable styles, and so they in turn served as models for Coltrane..." ${ }^{15}$ While each of these established tenor players had a distinctive style, they too were indebted to the modus operandi of Coltrane's most important influences. The model they provide for helping Coltrane reshape the lessons of Hawkins and

${ }_{9}$ Through personal communication, Ed Berger has pointed out that these characteristics existed well before the 1940s in music of Hawkins, Roy Eldridge, and Art Tatum. Many of these characteristics are associated with other prominent musicians of the period and earlier. I am not implying that Parker, Hawkins, and Gillespie were the only musicians to possess these musical characteristics, but that Coltrane strove to emulate these characteristics and it was through the musical influence of Parker, Hawkins, and Gillespie that Coltrane acquired these characteristics.

${ }^{10}$ Porter, John Coltrane.

${ }^{11}$ Porter, John Coltrane, 44.

${ }^{12}$ Ibid, 50.

${ }^{13}$ Ibid, 50.

${ }^{14}$ Porter, John Coltrane, 72.

${ }^{15}$ Ibid, 72. 
Parker to his own style was important; however, it is again the lessons of Hawkins and Parker, through the translation of other tenor players that influenced Coltrane most.

While there is always a large degree of musical development attributed to his time with Miles Davis and Thelonious Monk, ${ }^{16}$ the impetus for Coltrane's rapid development with Davis and Monk originates in the late 1940s and early 1950s. We are well aware that Coltrane was slow to develop musically. ${ }^{17}$ Discussing Parker's influence on Coltrane and Coltrane's slow development, Gillespie states,

At that time, [Coltrane's] phrasing resembled Charlie Parker's. It wasn't until later that he worked on finding his own style. You know, you can begin to build your own style on a single measure - and then everything starts to change in the way you perceive your music. Each time you pick up the horn again to play, this strange thing, this 'style' comes back: it's always there. Coltrane had been gone from me for quite a while before he was really able to construct his own style. ${ }^{18}$

While it is clear that Dizzy recognizes the influence Parker had on Coltrane early, this statement is valuable because it reminds the reader that it takes time for technique and stylistic traits to start to become evident in a musician's playing. While Coltrane made huge developmental strides playing with Davis and Monk, the seeds for this progress were sowed earlier, influenced by Parker, Hawkins, and Gillespie. Again, I stress that it is precisely because Coltrane was slow to develop that he was able to acquire a complete mastery over his instrument and idiom.

According to Jimmy Heath who spent significant time with Coltrane practicing and performing in Philadelphia, Coltrane was already working on melodic/rhythmic elements of sonic grounding that he would later focus on in his "Giant Steps" and "Countdown" performances. While describing Coltrane's early practice routine, Heath states, "Trane liked four-note patterns..." Heath then provides an example of a four-note melodic cell containing the 1-2-3-5 notes of a major scale or first four notes of a major pentatonic scale. ${ }^{19}$ This note collection

${ }^{16}$ Thomas and Cole both focus much of their attention on Coltrane's tenures with Davis and Monk. (See Bill Cole. John Coltrane. New York: Schirmer Books, 1976, 57 and 64; and J.C. Thomas Chasin' the Trane: The Music and Mystique of John Coltrane. New York: Da Capo Press, 1976, 84.) See also David Demsey, John Coltrane Plays Giant Steps. (Hal Leonard, 1996), 7.

${ }^{17}$ Ibid, 44, and Alyn Shipton, New History of Jazz. (London; New York: Continuum Press, 2001), 741.

${ }^{18}$ Shipton, Groovin' High, 235.

${ }^{19}$ Porter, John Coltrane, 66. 
is identical to the one Coltrane relies so heavily on in his solo constructions of both "Countdown" and "Giant Steps." Porter provides further evidence of Coltrane's early study of this essential melodic grouping by pointing out that, "On a Billy Taylor original entitled "Good Groove" Coltrane navigates the chord progression using little patterns of the sort that would obsess him eight years later." ${ }^{20}$ This note collection (1-2-3-5) provides the most essential elements of the sounding chord. It is no coincidence that Coltrane relied so heavily upon this note grouping and its variations to construct his solos on "Giant Steps" and "Countdown." This note grouping would allow Coltrane to express his unique harmonic progressions melodically in a clearly explicit way. This is one of the strongest elements of sonic grounding Coltrane uses; he begins using it early in his career and continues to employ explicit melodic/rhythmic patterns though his final recordings.

\section{STRAIGHT STREET AND MOMENT'S NOTICE}

It is during the years Coltrane spent with Miles Davis and Thelonious Monk that we can first identify substantial use of sonic grounding and restriction of materials in Coltrane's improvised solos as he begins to explore harmonic structure. This is because Coltrane is given more solo space in the bands he is playing in and because he has more decisive control over the songs he is performing. At this time, Coltrane sonically grounds his solos by using smooth melodic voice-leading. He restricts his solo material by explicitly implying the intention of his harmonic progression using chord-tones. The harmonic progressions he implies are often non-diatonic substitutions on standard jazz repertoire or prescribed chromatic harmony on original compositions. The use of nondiatonic harmonic progressions are more obscure when he uses them as substitutions for standard jazz progressions and become more clear in his original compositions.

Superimposing chord substitutions over standard harmonic progressions is an important aspect of Coltrane's improvisation style, and the first instance that Coltrane restricts improvisation to very specific elements. Coltrane employed chord substitutions often, and in a very clear and explicit way, particularly on jazz standards or songs that were not his own. Porter aptly describes Coltrane's improvisation style and his use of chord substitutions in the mid 1950s by stating:

${ }^{20}$ Ibid, 87 (This performance is from the 1951 live radio broadcasts of Gillespie's small group from Birdland in New York City.) 
Harmonically, Coltrane's melodic lines typically enriched the chord progressions by suggesting upper extensions, and substitute chords. For example, a simple ii- $\mathrm{V}^{7}-\mathrm{I}$ progression might be interpreted as if it were $\mathrm{ii}^{{ }^{67}-}$ $\mathrm{V}^{7(\mathrm{b5})}-\mathrm{I}$, that is, adding upper extensions; or, substituting for the $\mathrm{V}^{7}$, he might interpret it as ii-bII ${ }^{7}-\mathrm{I}$. These alternate progressions might be clearly implied in his improvised melody line, even if the rhythm section accompanists continued to play the basic ii- $\mathrm{V}^{7}-\mathrm{I}$ progression... Coltrane used these substitutions more frequently then his peers and with greater daring - that is, implying changes more remote from the original. ${ }^{21}$

Coltrane's use of upper extensions and chord substutions in his improvised solos is directly related to his focus on melodic voice-leading; an influence from the improvisational techniques of Parker, Hawkins, and Gillespie. By the time he starts performing with Davis and Monk, Coltrane has absorbed the lessons of his early influences; the skills he acquired allow him to explore different ways of navigating chord progressions. By using chord substitutions in a very isolated way, he was able to hear the tonality of the substitution. In justifying his choice of notes and melodic phrasing in an interview after his Giant Steps recording, Coltrane states "I haven't played them enough, and I'm not familiar with them enough yet to take one single line through them, so I play all of them-you know, trying to acclimate my ear, so I can hear."22 Although Coltrane said this in 1960, it sheds some important light on his process of melodic voice-leading development throughout his career. The harmonic intentions of his improvised melodic lines are always explicit, he never tries to obscure what he is attempting to imply harmonically through his melodic lines. This comes from his attempt to "acclimate his ear" so that he can hear and internalize these harmonic pathways more clearly. Coltrane restricts the focus of his improvised solos to the development of the harmonic structure; in this case, as a substitution over standard harmonic progressions in an attempt to master multiple pathways through the harmonic structure. Coltrane creates these strong, clear, and often times chromatic lines regardless of whether the rhythm section is playing the substitution with him or not.

In his article "We Are Revealing a Hand That Will Later Reveal Us" John Schott separates Coltrane's use of substitutions on standard jazz repertoire and his use of chromatic harmony on original compositions into two contrasting approaches to chromaticism. He states, "To begin with, we must distinguish between two approaches to chromaticism in Coltrane's early work: that which is consonant with the underlying harmony, but following that harmony, modulates

${ }^{21}$ Ibid, 124

${ }^{22}$ Quoted, Ibid, 158 
to remote regions or fails to establish any key center; and that which extends, alters or superimposes upon the underlying, tonic-oriented harmony, and thus is dissonant to it."23 Schott identifies two different approaches to Coltrane's use of chromaticism. I view Coltrane's use of chromaticism as two sides of the same coin. Both his use of chord substitutions that go out of the key and create dissonance on jazz standards, and the pre-composed chromatic harmonic progressions of his original compositions are attempts to explore different pathways through the music and to connect these pathways in fluid and seamless melodic phrases. Both are aimed at mastering and extending the standard harmonic structure of jazz improvisation. The difference between Coltrane's two approaches to chromaticism is not Coltrane's playing. The difference is determined by how much control and decision-making Coltrane had over the composition being performed. Coltrane performed much of his melodic substitutions over jazz standards as a sideman in other bands. He had no control over how the rhythm section was accompanying him and so he experimented with different harmonic pathways melodically substituting different harmonic progressions over what the rhythm section was performing, thus creating a considerable degree of dissonance.

Many of Coltrane's earliest recorded compositions present the clearest indication of what he was working on in his attempts to master harmonic structure. In the liner notes to Giant Steps, Nat Hentoff quotes Coltrane describing his composition process. Coltrane states "I sit there and run over the chord progressions and sequences, and eventually, I usually get a song-or songs—out of each little musical problem...After I've worked it out on the piano, I then develop the song further on the tenor, trying to extend it harmonically." ${ }^{24}$ This statement emphasizes Coltrane's focus on harmonic aspects of musical structure over other aspects. Coltrane is specifically concerned with harmonic structure and musical pathways. What I mean by this is that Coltrane is interested in the many different harmonic ways one might get from the beginning of a phrase to the cadence at the end.

The fact that this quote appears on the liner notes to Giant Steps provides evidence that his early composition process was informed by the searching quality of harmonic development that would eventually lead to the Giant Steps recording. Looking at some of his earliest recorded original compositions, we are able to see Coltrane's interest in exploring harmonic progression clearly laid out.

${ }^{23}$ John Schott, "We Are Revealing a Hand that Will Later Reveal Us: Notes on Form and Harmony in Coltrane's Work" (Arcana: Musicians on Music, ed. John Zorn, New York, NY; Hips Road and Granary Books, 2000), 348.

${ }^{24}$ Quoted in Porter, John Coltrane, 117. 
"Nita," "Just For the Love," "Straight Street," "Black Pearls," "Moment's Notice" and "Lady Bird" are all excellent examples of Coltrane isolating and working out different harmonic pathways. ${ }^{25}$ Shott readily concedes, "Coltrane's ornate, dense improvisations on the chord changes of blues and standards are a logical extension of the practice of Dizzy Gillespie." However, he states that "The chromaticism of Moment's Notice, and later Giant Steps and Satellite, is fundamentally different than that which had preceded it...The appearance of any key center is so fleeting in these pieces that the bebop soloist's arsenal of upper-structure extensions, passing tones, and substitutions is useless." ${ }^{26}$ I must disagree with Shott's assertion that these processes are fundamentally different. Coltrane's use of chord substitutions on jazz standards and his use of pre-composed chromaticism on original compositions are separated by degree and not fundamentally different. The degree of difference resides in the amount of control Coltrane had over the compositions being performed. In his improvised solos on standard jazz repertoire, there is a higher degree of dissonance because the rhythm section was not also playing these substitutions. When performing his own compositions, Coltrane had the ability to dictate to the rhythm section the specific harmonic progression he wished to explore. Coltrane's improvised melodic lines adhere closer to the pre-composed harmonic progression because he has decided what it should be; the degree of dissonance is much lower because the rhythm section is in accord with his harmonic pathway.

"Straight Street," one of Coltrane's earliest recorded original compositions, provides an excellent example of a variety of harmonic progressions Coltrane was studying. ${ }^{27}$ Measures 1 through 5 comprise a chain of secondary dominant chords coupled with their relative ii chord to create groups of ii- $V^{7}$ progressions descending by whole-steps. Measures 6 through 9 begin with the same ii- $V^{7}$ grouping and descend by half steps. On the bridge, Coltrane displays an example of his skill in melodic voice-leading when he places the $\mathrm{G}^{\mathrm{b}} / \mathrm{F}^{\#}$ melodic note over a number of different chords. I have placed the chord-tone relationships in parenthesis underneath the melody in the first nine measures of the bridge (see figure 1).

Examining the first five measures of Charlie Parker's original bebop composition "Confirmation," it is clear that the progression moves from the I chord, F major, to the $\mathrm{IV}^{7}, \mathrm{~B}^{\mathrm{b}}$. There are a few ways to interpret the chord progression

${ }^{25}$ It should also be mentioned that Coltrane's "Straight Street" and "Moment's Notice" share similarities to Benny Golson's "Stablemates," which is most likely a result of the two saxophonists growing up together in Philadelphia.

${ }^{26}$ Schott, 349.

27 "Straight Street," September 21, 1957, Whims of Chambers, (Blue Note Records BST 81534). 
from measure 1 to measure 5. I have included three possible interpretations in Roman numeral analysis below the measures. What is clear, however, is Parker's use of secondary ii- $\mathrm{V}^{7}$ groupings descending by whole steps in measures 2 through 4 to embellish what would otherwise be a stagnant chord progression, (I to $\mathrm{IV}^{7}$, see figure 2).

Comparing the first five measures of "Confirmation" to the first five measures of "Straight Street," we see a very similar progression. Like "Confirmation," the target measure of this portion of "Straight Street" is measure 5-in Coltrane's case the $\mathrm{i}$ minor chord, $\mathrm{E}^{\mathrm{b}} \mathrm{m}^{7}$. Coltrane uses the same secondary ii- $\mathrm{V}^{7}$ groupings descending by whole steps, only in Coltrane's composition he begins the wholestep sequence a whole step higher then Parker, and uses this first ii- $\mathrm{V}^{7}$ to replace what would have been an $\mathrm{A}^{\mathrm{b}}$ chord in bar one, had he followed Parker's model exactly (see figure 1).
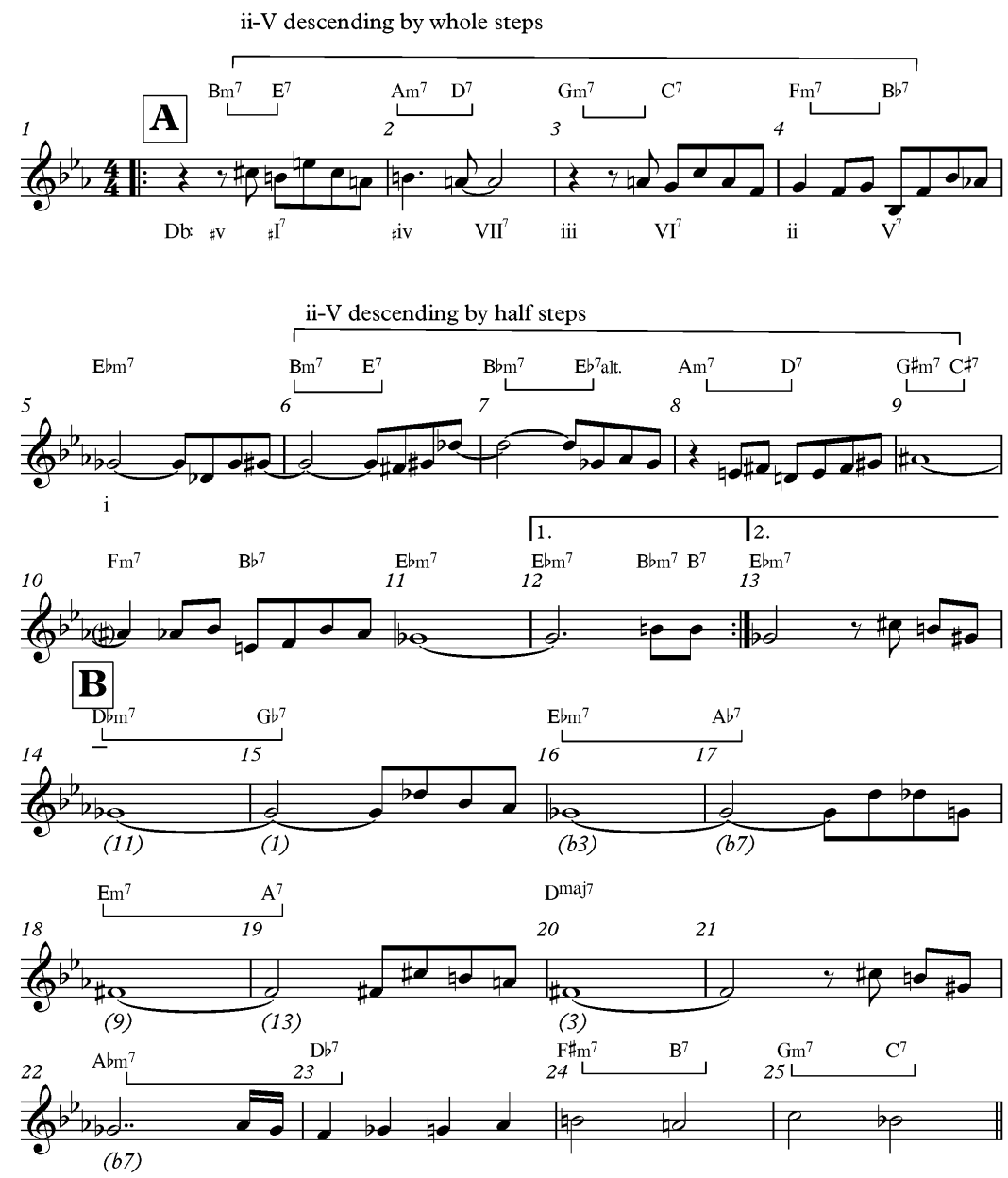

Figure 1. "Straight Street" with harmonic analysis. 

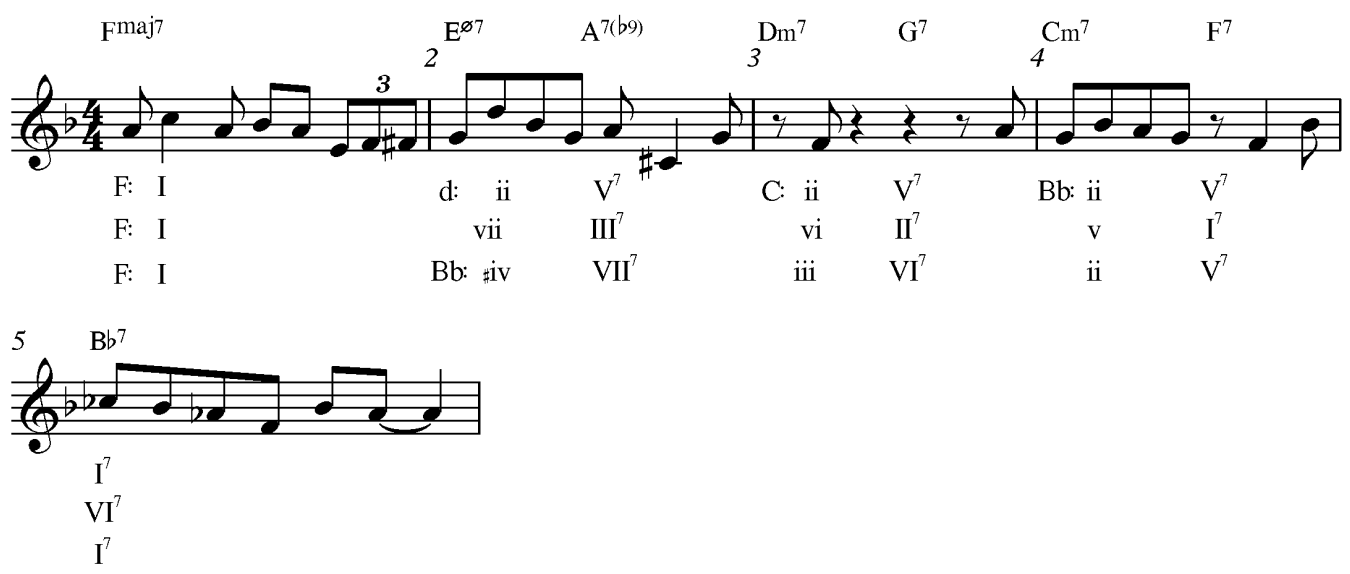

Figure 2. "Confirmation," harmonic analysis of first five bars.

"Straight Street" provides an excellent example of the harmonic pathways Coltrane was exploring early on in his musical development. There are also elements of the harmonic embellishments employed later in "Moment's Notice," used in the bridge of "Straight Street." 28 This is proof of Coltrane's statement quoted above, that he sometimes composed more than one song focused on the same harmonic problem. The harmonic motion of measures 16 through 21 in "Straight Street" is identical to the harmonic motion in measures 1 through 3 and 5 through 7 of "Moment's Notice."
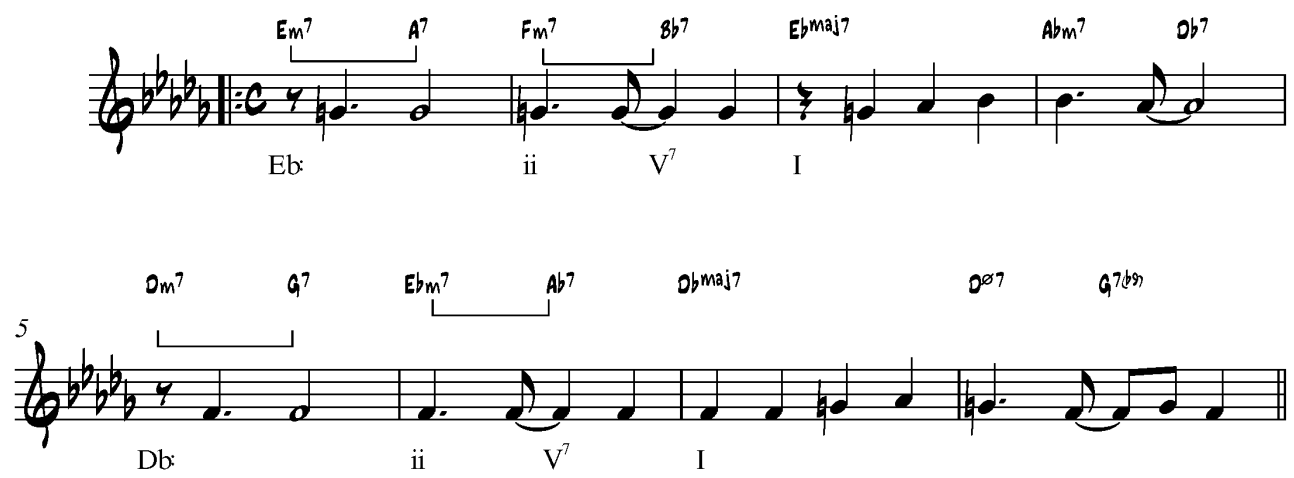

Figure 3. First eight measures of "Moment's Notice."

28 “Moment's Notice," September 15, 1957, Blue Trane, (Blue Notes BST 81577) 
Similarly, Porter has made a number of connections between Coltrane's early compositions and his later work like "Giant Steps." ${ }^{29}$ Porter points out that one of Coltrane's first recorded compositions, "Nita," introduces the fast-moving ii$\mathrm{V}^{7}$-I sequences a third apart that fascinated Coltrane and eventually culminates in the composition "Giant Steps." ${ }^{30}$ Porter also makes the connection between Coltrane's early compositions and his earliest influences. In his analysis of Coltrane's early composition, "Just For the Love," Porter notes, "after a few hearings it becomes clear that Parker was his inspiration." ${ }^{31} \mathrm{He}$ also points out that in "Just for the Love" we see another relationship of major chords in thirds (moving from $\mathrm{A}^{\mathrm{b}}$ Major to $\mathrm{F}$ Major in the first two bars). ${ }^{32}$ Furthermore, "Just For the Love" could be grouped with "Straight Street" and "Moment's Notice," as a third song containing the harmonic embellishment ii- $\mathrm{V}^{7}-\mathrm{I}$ preceded by a ii$\mathrm{V}^{7}$ a half step below. In "Just for the Love," the harmonic embellishment is part of the turn around (bars 11 and 12 gonging back to the top of the form).
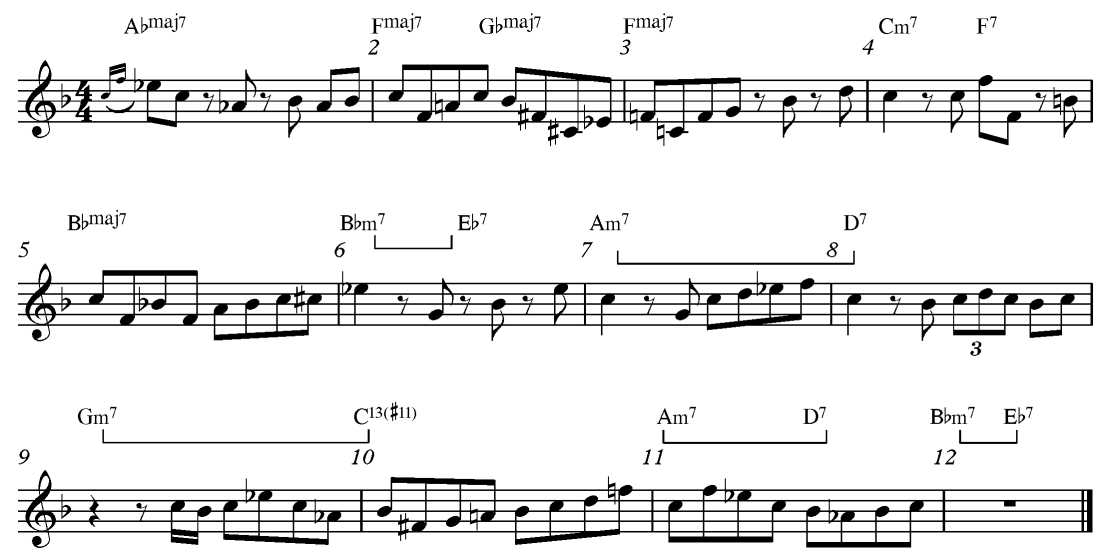

Figure 4. "Just for the Love"

These music examples are further proof of Coltrane's composition process, and his inclination to isolate and explore specific musical pathways. In "Just for the Love" the series of chromatic ii-Vs solves the harmonic "problem" of modulating from the expected cadence in measure 11 , to $F$, to the deceptive $A^{b}$ Major in

${ }^{29}$ I must also note that Jason Lyon's article "Coltrane's Substitution Tunes" was pivotal in helping me develop a framework for discussing Coltrane's musical development in a fluid manner and I will use his analysis and attempt to expand on it further on in my article. (Jason Lyon "Coltrane's Substitution Tunes" www.opus28.co.uk/jazzarticles.html)

${ }^{30}$ Porter, John Coltrane, 115

${ }^{31}$ Ibid, 116

${ }^{32}$ Ibid, 117 
measure one. Instead of the typical blues turn around of iii-VI-ii-V, to F major in measure one, we have a modulation from the iii chord in $\mathrm{F}$ to $\mathrm{A}^{\mathrm{b}}$ Major.

Jason Lyon has convincingly shown a very logical progression from "Moment's Notice" through "Lazy Bird" to "Giant Steps" and "Countdown" in his perceptive analysis "Coltrane's Substitution Tunes." He states, "These revolutionary compositions are a direct result of Coltrane's exhaustive exploration of harmonic theory... All of these tunes are primarily concerned with harmonythat is to say, the chord changes are what's compositionally most important. There are some interesting observations to be made by looking at these tunes as a group. There is a thread running through them-a continuity of purpose."33

Additionally, Porter links "Moment's Notice" to Dizzy Gillespie's composition "Con Alma" and while discussing the harmonic progression of "Moment's Notice," he concludes, "I would suggest that sequences like these led partially to the unusual chord sequence of "Giant Steps." ${ }^{34}$ This is the same conclusion arrived at by Lyon in his analysis of "Moment's Notice," "Lazy Bird," and "Giant Steps." 35

While many, including Porter state, that "Giant Steps" "represents the culmination of Coltrane's developing interest in third-related chord movement," ${ }^{36}$ I would go further and state that "Giant Steps" and "Countdown" represent the culmination of Coltrane's desire to master the structural elements of harmony, which began in the late 1940s with his earliest influences. Although Porter cautions that the origins of the chord progressions of "Giant Steps" "in Coltrane's mind are of course not possible to trace," 37 there are a number of earlier connections: all of Coltrane's preoccupation with chord progression and his continual extension and embellishment of the ii- $\mathrm{V}-\mathrm{I}$ cadence lead directly to the "Giant Steps" harmonic progression. Thus far, we have seen that Coltrane has focused his musical development on the mastery of traditional harmonic structure in jazz improvisation. He has done so by isolating specific chord sequences. $\mathrm{He}$ has relied upon the sonic grounding of chord tones and smooth melodic voice-leading to explicitly state his intentions of chord substitutions and precomposed chromatic harmony. We shall see with Coltrane's performances on "Giant Steps" and "Countdown," the culmination of all of these techniques and the emergence Coltrane's virtuosic display of mastery over traditional harmonic structure.

${ }^{33}$ Jason Lyon "Coltrane's Substitution Tunes" www.opus28.co.uk/jazzarticles.html

${ }^{34}$ Porter, John Coltrane, 128

${ }^{35}$ Jason Lyon “Coltrane's Substitution Tunes" www.opus28.co.uk/jazzarticles.html

${ }^{36}$ Porter, John Coltrane, 145

${ }^{37}$ Ibid, 145 


\section{GIANT STEPS AND COUNTDOWN}

Coltrane reaches a climax of using densely prescribed harmonic progressions with restricted explicit melodic elements on the recordings of "Giant Steps" and "Countdown." At this same point, Coltrane refines his melodic voice-leading to its most essential elements: arpeggios and pentatonic scale fragments. To reiterate, he remains heavily reliant on pentatonic scale fragments in the music he makes until his death. Coltrane is intensely focused on mastering and integrating prescribed harmonic progressions with smooth melodic voice-leading into his original compositions. At this brief moment in time we see the culmination of all of the work that Coltrane accomplished up until this point clearly laid out, before he transitions from prescribed to internalized harmonic structure.

At this point in his career, Coltrane is more like a scientist in a lab creating musical experiments than he is an entertainer. Both "Giant Steps" and "Countdown" have a very exercise-like quality to them. In fact, Coltrane is conscious of this point and is clearly concerned as well. On the back cover of the album he states, "I'm worried that sometimes what I'm doing sounds just like academic exercises, and I'm trying more and more to make it sound prettier." ${ }^{38} \mathrm{I}$ identify these two compositions and the way they were performed as the culmination of Coltrane's mastery of pre-composed harmonic structure because at no other time prior to them do we see such a quickly moving harmonic progression passing though such distant key centers. There are earlier compositions that do explore equally distant key centers and there are also compositions that feature just as quickly moving harmony; however, with "Giant Steps" and "Countdown" Coltrane combines the distant ranging harmonies together with the quickly moving chord progressions that culminate in his most extreme examples mastery over structured harmonic pathways through music.

\section{GIANT STEPS}

Coltrane restricted his focus to very specific harmonic voice-leading in his improvised solos on "Giant Steps" and "Countdown." I will elucidate this point by comparing two of Coltrane's improvised solos on "Giant Steps." It will become clear that Coltrane was striving to master smooth melodic lines containing note choices that depict the essence of each chord. With his publication Coltrane Plays Giant Steps," David Demsey has provided nine different tran-

\footnotetext{
${ }^{38}$ Quoted on the back cover of Giant Steps, 1959.
} 
scriptions of Coltrane improvising on "Giant Steps." It is interesting to note the similarities and differences between all of these solos. Demsey states,

Much has been made of the melodic patterns [used in Coltrane's solos,] with some calling Coltrane's solos overly repetitive; this misses the much more important point of the smooth connections made between these patterns, effortlessly moving between the three different key centers... These key-to-key connections are created by Coltrane's brilliant use of voice-leading; within his melodic lines, the tones of each chord flow to the tones of the next chord using only half-step motion or commontones, in the same way that a jazz pianist creates chord voicings. ${ }^{39}$

Two particular versions of "Giant Steps" clearly show Coltrane's improvising process and voice-leading goals. Coltrane recorded the first version on March 26, 1959. It is the eighth take of the recording session and it features pianist Cedar Walton, bassist Paul Chambers, and drummer Lex Humphries. Atlantic did not release this version on the original LP but it has been included on subsequent reissues. ${ }^{40}$ Coltrane recorded the second version, (Take 5) at a May 5 recording session, which features pianist Tommy Flanagan, bassist Paul Chambers, and drummer Art Taylor. Atlantic issued this version on the original Giant Steps album released in 1959..$^{41}$ The earlier solo (Version 1, Take 8, March 26,) begins with a repeated dotted quarter and eighth note rhythmic theme, the simplicity of which gives the listener the impression that Coltrane is building his intensity for the coming choruses. The rhythmic variation in the first chorus gives the solo a more lyrical feel then the first chorus of version 2, (Take 5, May 5 recording session). This version begins with a stream of eight notes from the very first phrase, giving it less melodic development and making it more dependent on the harmonic motion. A close analysis of Version 1 makes it obvious that the lyrical, melodic nature of this solo is limited to the opening chorus. The opening four measures of the solo are virtually identical to Take 7 from the same recording session. ${ }^{42}$ Coltrane was trying to communicate something important in these opening four measures of his solo. However, it is interesting that Coltrane chose to release the second version instead of the first. From the very first notes of the second solo, Coltrane is dedicated to arpeggios and the permutation of pentatonic patterns with very little rhythmic variation or melodic development. Demsey

${ }^{39}$ Demsey, John Coltrane Plays, 12

${ }^{40}$ John Coltrane, "Giant Steps (Alternate Take)," April 1, 1959, Alternate Takes, (Atlantic SD 1668)

${ }^{41}$ John Coltrane, "Giant Steps," May 4, 1959, Giant Steps, (Atlantic SD 1311)

${ }^{42}$ Demsey, John Coltrane Plays, 33 
characterizes all of the versions recorded on May 5 stating, "By now, Coltrane appears to have been practicing the changes at a faster tempo. Although the energy level is noticeably higher than in the March sessions, the vocabulary is more ingrained or "pre-learned" than it had been a month earlier." 43

Porter adds his impression of the March 26th version of "Giant Steps," stating, "The take 8 of "Giant Steps" that was issued in 1974 moves at a pace of 260 beats per minute, slower then the originally issued recording. At the slower tempo Coltrane sounds more relaxed and more lyrical...This earlier version of "Giant Steps" provides instructive examples of the ways that Coltrane manages to avoid the somewhat mechanical quality of playing patterns." ${ }^{34}$
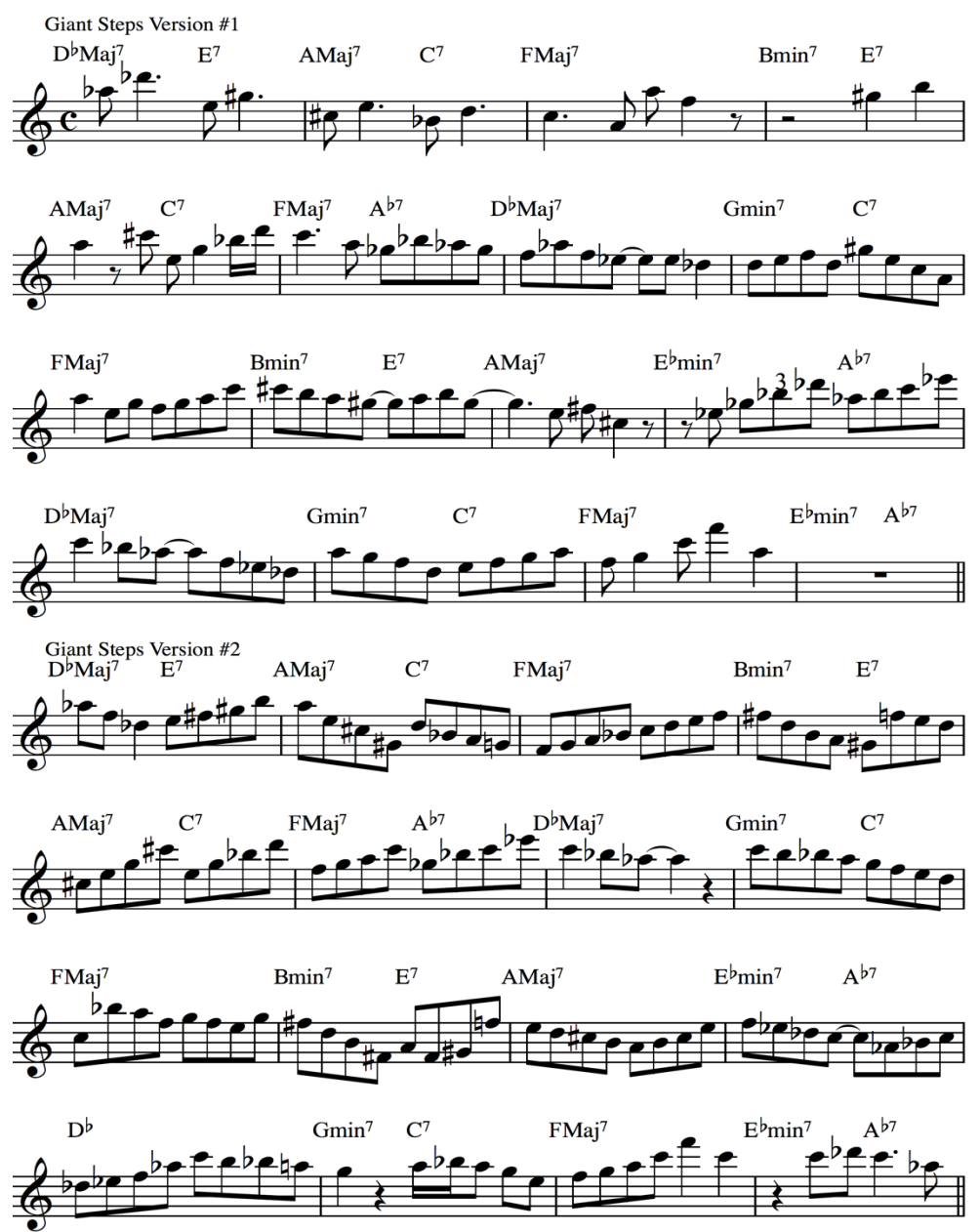

Figure 5. "Giant Steps" Version 1, Take 8, March 26) and Version 2 Take 5, May 5.

${ }^{43}$ Ibid, 10

${ }^{44}$ Porter, John Coltrane, 153 
Why then did Coltrane prefer to use his second solo, instead of the first? I argue that Coltrane was more concerned with the manipulation of arpeggios and pentatonic patterns over the chord changes rather than developing an organically paced, contoured solo. The originally released version of "Giant Steps" presents very concise melodic lines that depict the most essential elements of the precomposed harmonic progression.

Porter identifies three elements of melodic construction in the "Giant Steps" solos: arpeggios, neighbor tones and pentatonic patterns. In describing, the nature of the melodic patterns found in Coltrane's improvised solo on "Giant Steps." Porter states, "One basic pattern, involving the first, second, third, and fifth degree of each key, appears many times. This use of "pentatonic patterns," as they are called (because the sixth of the scale, which is omitted, would make it a pentatonic scale), is widespread today, primarily through Coltrane's influence. ${ }^{45}$ Both arpeggios and pentatonic scale patterns help to clearly outline the harmonic progression. Pentatonic pattern permutations provide the most essential material for melodic development. ${ }^{46}$ Coltrane was certainly aware of the strong melodic foundation that pentatonic scales have in folk music throughout the world. In an interview given in Paris in 1963 he states:

There's a lot of modal music that is played everyday throughout the world. It's particularly evident in Africa, but if you look at Spain or Scotland, India or China, you'll discover this again in each case. If you look beyond the differences in the style, you will confirm that there is a common base. That's very important. Certainly, the popular music of England is not that of South America, but take away their purely ethnic characteristics - that is, their folkloric aspect-and you'll discover the presence of the same pentatonic sonority, of comparable modal structures. It's this universal aspect of music that interests me and attracts me; that's what I'm aiming for. ${ }^{47}$

Although Coltrane made this statement in 1963, it is evident by the melodic material Coltrane was using when he recorded "Giant Steps" that he was consciously using pentatonic patterns to outline chord changes. As a result, by refining much of his solo material to pentatonic patterns Coltrane was able to capture the most essential sound of each chord. Hafez Modirzadeh also agrees that at this point in his improvisations Coltrane is relying on "the inverting of

${ }^{45}$ Ibid, 151

${ }^{46}$ See Jerry Bergonzi, Melodic Structures, Inside Improvisation, Vol.1 (West Germany, Advance Music, 1992)

${ }^{47}$ Lavezzoli, The Dawn of Indian Music, 282 
basic chordal harmony, perceivable through pentatonicism... and sequences built off the chord degrees of 1-2-3-5, perceived as stemming from the pentatonic cycle." ${ }^{48}$

The essential melodic tones of the pentatonic scale act as sonic grounding an identifiable reference point for both Coltrane and the listener. In the performances of "Giant Steps" and "Countdown," Coltrane uses sonic grounding to capture the essence of the harmonic progression in a melodic phrase. He provides a point of reference by playing something very explicit that outlines the chord progression and allows the listener to easily hear the underlying harmony of a melodic line. The simplest and most obvious treatment of sonic grounding is the triad. Triads, regardless of quality, are very explicit in their harmonic intention. Arpeggiated seventh chords also contain strong harmonic grounding. Pentatonic scales, as Coltrane indicated above, possess strong sonority and provide content that is more characteristically melodic. Coltrane favored a variety of four-note groupings or permutations of pentatonic patterns, pairing them with arpeggios to create his "Giant Steps" improvised solo.

\section{COUNTDOWN}

"Countdown" represents an important collection of compositions that apply the results of Coltrane's "Giant Steps" chord substitutions to well-known jazz standards. These songs include "Countdown" based on Eddie Vinson's "Tune Up," "26-2" based on "Confirmation," "Fifth House" based on "What is This Thing Called Love," and "Satellite" based on "How High the Moon." ${ }^{49}$ This group of compositions reveals further impact of Coltrane's earliest influences. They directly reference the practice of using the harmonic structure of a wellknown song to compose a new composition, sometimes with an elaborated chord progression. This type of composition, known as a contrafact in jazz, comprises a large percentage of Parker's original compositions. Demsey states, in composing "Countdown," Coltrane "uses a compositional process which is usually identified with the bebop era of the late forties: the creation of a new melody on an existing

\footnotetext{
${ }^{48}$ Hafez Modirzadeh, "Archetypes and Cyclic Perspectives in the Work of John Coltrane and Ancient Chinese Music Theory." (Black Music Research Journal, Vol. 12, No. 1 (Spring, 2001), pp.75-106,) 92-94

${ }^{49}$ When Coltrane uses his "Giant Steps chord substitution" on other songs, the substitution is often referred to as a Tri-Tonic substitution because the progression contains the dominant and tonic chord of three tonalities a major third apart. Coltrane also applied these tri-tonic substitutions on other jazz standards but kept the original melodies intact. See Demsey, John Coltrane, 67 for a complete list of song that Coltrane employed tri-tonic chord progressions.
} 
chord progression." ${ }^{50} \mathrm{I}$ think it is important to note that of the four songs just listed, one -“26-2" -is based on an original bebop composition by Parker, and two, "Satellite" and "Fifth House" are based on jazz standards that are associated with both Parker and Gillespie's performance repertoire. There is further evidence that Coltrane had original compositions based on the jazz standards, "Cherokee" and "All the Things You Are," ${ }^{11}$ both of which were also particular favorites of Parker and have a bebop melody associated with them. It is no coincidence that Coltrane relied upon standard repertoire so closely related to Charlie Parker to compose his own contrafacts.

"Giant Steps" is a prototype, an original composition that splits the octave into three equal key centers in a usable cyclical harmonic progression. "Countdown" is Coltrane's first recorded attempt at applying this cycle over standard functional harmony. ${ }^{52}$ We have already seen Coltrane extend the resolution of a harmonic progression by stacking up ii- $\mathrm{V}$ progressions both chromatically and in whole-steps before the ii chord in the target key. (See "Straight Street" and Moment's Notice" above.) However, with "Countdown," Coltrane extends the harmonic progression by pushing the ii and the $\mathrm{V}^{7}$ chord away from each other. In the space between, he inserts $V^{7}-\mathrm{I}$ resolutions to keys that descend by a major third to the target key. In describing the use of Coltrane's harmonic chord sequence on "Countdown," Porter states that, "Coltrane replaces each of the ii$\mathrm{V}^{7}$-I progressions of the original [the song "Tune Up"] with his substitute formula." ${ }^{53}$ However, this statement is inaccurate in its description of what Coltrane does. He does not replace the original ii-V-I progressions. The original progression of "Tune up" still exists; Coltrane pushes the $V^{7}-\mathrm{I}$ cadence to the far end of the four bar phrase separating the ii and the $V$ by two full measures and in the created space adds the extra chords.

Coltrane's improvised solos on two commercially released versions of "Countdown" are similar in their melodic material to his solos on "Giant Steps." He relies heavily on pentatonic permutations, arpeggios, and neighbor tones to construct his melodic phrases. As a comparison, he uses pentatonic permutations 85 times in the first 11 choruses of the master take of "Giant Steps" and 58 times in 8 choruses of the master take of "Countdown."

${ }^{50}$ David Demsey, "Chromatic Third Relationships in the Music of John Coltrane." Annual Review of Jazz Studies 5 (1991): 145-80. 160

${ }^{51}$ Porter, John Coltrane, 148; and Demsey, John Coltrane, 67

${ }^{52}$ There is not a lot of evidence that Coltrane conceived of "Giant Steps" first and "Countdown" after. In fact, they probably were developed simultaneously. However, because "Giant Steps" is a self-contained original composition and "Countdown" is based on a pre-existing harmonic structure, I believe priority should be given to the original.

${ }^{53}$ Porter, John Coltrane, 147 
Up to this point Coltrane has been focused on developing skills that would allow him to perform melodic lines that outlined harmonic progressions through step-wise voice-leading. This mastery of harmonic structure began with his interest in melodic voice-leading peaked by his early musical influences. $\mathrm{He}$ spent his time with Davis and Monk becoming familiar with chromatic voiceleading and employing chord substitutions over standard chord changes. $\mathrm{He}$ wrote original compositions employing many of the same chromatic chord substitutions. He began performing these original compositions and he use them to shape the way the rhythm section accompanied him, diminishing the degree of dissonance his earlier melodic lines created against standard harmonies. Coltrane's exploration of pre-composed, structured harmonic progressions and smooth voice-leading culminated in the performances of "Giant Steps" and "Countdown." His improvised melodic lines in these performances are smoothly led though distant keys as he captures the essential harmonic elements of each chord through the sonic grounding of pentatonic patterns.

One might wonder how Coltrane might progress from such a mastering of dense harmonic structure. In his research on Coltrane, Carl Woideck provides some insight into why Coltrane continued to develop his music. He States,

From one point of view, Coltrane had pushed jazz harmonies as far as they could go. From another, such complex, sophisticated knowledge builds its own trap, and Coltrane, still a vertical thinker, was like a hamster trapped in a three dimensional harmonic maze of his own making. ${ }^{54}$

Coltrane continued to perform songs containing the dense harmonic progressions he had developed with "Giant Steps" and "Countdown" throughout the early 1960s. However, he identified a problem in the way the rhythm section was performing these dense harmonies. The harmonic structure he sought to master became confining and ridged in its pre-composed form. The solution was to significantly alter the way the rhythm section accompanied him rather than drastically alter his own way of playing. Coltrane credits Miles Davis with helping him find the solution. He states, "It was hard to make some things swing with the rhythm section playing those chords, and Miles advised me to abandon the idea of the rhythm section playing those sequences, and to do it only myself." ${ }^{\prime 5}$ Having captured the essential sound of each chord using four note permutations of pentatonic patterns, Coltrane was able to discontinue the

\footnotetext{
${ }^{54}$ Carl Woideck, The John Coltrane Companion: Five Decades of Commentary, (New York: Schirmer Books, 1998) 44

${ }^{55}$ Coltrane quoted in Shipton, New History of Jazz, 752
} 
quickly moving chord changes played by the rhythm section. He did continue to express the harmonic progressions in his melodic lines.

What Coltrane chooses to retain and discard from his experiments on "Giant Steps" and "Countdown" are very clear in the recordings made around the same time. The primary changes made are in the way the rhythm section accompanies Coltrane, providing more of an ostinato vamp to many of the songs. Coltrane, uses ostinato vamps to break up the densely moving chord changes, or sometimes underneath these changes, to allow the bass and drums a better chance of settling into a groove. At this point in Coltrane's performances the ostinato and rhythmic groove of the rhythm section takes on an additional role of sonic grounding. The repetition in the rhythm section groove provides a point of reference on which Coltrane is free to imply the densely moving harmonic progressions.

One composition, released shortly after his Giant Steps album, "Fifth House," shows the modifications of the rhythm section's accompaniment of the substitution patterns. "Fifth House" features a repeated ostinato in the A sections while Coltrane's melodic line outlines the tri-tonic harmonic progression. Coltrane still has the rhythm section perform the quickly moving tri-tonic chord progressions during the bridge of the composition. After Coltrane's solo the pianist solos over the original changes of the song, "What is This Thing Called Love." Subsequent recordings begin to follow the same trend of simplifying the role of the rhythm section, letting them focus on the groove while Coltrane implied the chord substitutions on top of the rhythm section's ostinato or vamp. The use of ostinato bass grooves around 1960 was certainly not new for Coltrane; he often used pedal points in his earlier compositions to provide contrast to sections containing faster moving harmonic motion. He also used them to build momentum at the end of forms. Porter traces Coltrane's interest in vamping harmony and ostinatos as far back as his time performing in Gillespie's big band in the late 1940 s. ${ }^{56}$

\section{MY FAVORITE THINGS}

Taking Miles's suggestion, Coltrane stopped using dense harmonic progressions. Instead, he directed the rhythm section to play more modal with pedal point ostinato accompaniment. This allowed his best-known rhythm section to

${ }^{56}$ Porter points out that Coltrane was playing in Dizzy's band at a time when Dizzy was performing a number of vamp ostinato and Latin inspired songs, including "A Night in Tunisia" "Manteca" and "Cubano Be Cubano Bop," Porter, John Coltrane, 78. For more information on Ostinato in African American Music see Wendell Logan, "The Ostinato Idea in Black Improvised Music: A Preliminary Investigation" (The Black Perspective in Music Vol. 12, No .2 (Autumn 1984) 193-215) 
develop their signature groove that propelled Coltrane's creativity even further. ${ }^{57}$ "My Favorite Things" recorded in 1960 proves to be the epitome of the style of composition that Coltrane would use to continue his exploration and mastery of structural elements moving forward. The song quickly became his most popular and enduring, and he continued to perform it night after night up until his death in 1967. The song features many characteristics that help us to understand the direction Coltrane takes in applying his harmonic explorations on top of an ostinato based rhythmic accompaniment. Both Porter and Kofsy provide useful analysis of the recorded performance of "My Favorite Things." 58 The characteristics of Coltrane's arrangement of the composition most pertinent to this study are the organization and structure of the solo section. Each solo section is open ended and the duration of each solo is determined by the soloist who plays a portion of the melody as a cue to move on to the next section. Solos generally consist of one open form vamp in minor tonality and one open form vamp in major tonality. There are at least ten different live recordings of Coltrane performing "My Favorite Things" and he keeps this solo format consistent for his solo in virtually every performance. With his frequent performances of "My Favorite Things," Coltrane begins to explore and move beyond the restricting prescribed structural elements of cyclical form, which was pervasive throughout jazz at the time. In performances of "My Favorite Things," Coltrane does not have to concern himself with pacing his solo to align with the customary structure of a cyclical form that repeats every 12, 16, or 32 measures. He is not required to shape his solo around strong harmonic resolutions at the end of each chorus, instead he is free to pace his solo as he sees fit. Additionally, with a section in minor and one in major, "My Favorite Things" is a platform for Coltrane to explore chromaticism in a variety of ways based on both the minor and major relationships. One might argue that non-diatonic chromaticism becomes ambivalent of tonality as the soloist applies it more liberally. However, despite the ever-increasing liberal use of non-diatonic chromaticism in Coltrane's solos on "My Favorite Things," the listener can always hear when he shifts from soloing on minor to major, even without the customary melodic line that announces the transition. After the recording of "My Favorite Things," Coltrane begins to perform more often on vamp style songs with indeterminant formal structures, eschewing cyclical form so that he can imply formal structure in the same manner that he implies harmonic structure: at his own discretion.

${ }^{57}$ Coltrane's most well-know rhythm section consisted of pianist McCoy Tyner, drummer Elvin Jones and bassist Jimmy Garrison.

${ }^{58}$ See Porter, John Coltrane, 182; and Frank Kofsky, "Elvin Jones Part II: Rhythmic Displacement in the Art of Elvin Jones," (Journal of Jazz Studies Vol. 4 N2 Spring/Summer 1977,) 21-23 


\section{MILES' MODE}

In 1962 Coltrane and the solidified version of his famous rhythm section made their first small group recording with their trademark groove in full swing. This recording, simply called Coltrane, was yet another landmark on Coltrane's developmental continuum. ${ }^{59}$ The tracks on this recording show a decided turn towards creating a strong groove in the rhythm section. Many of the tracks on the album have modal harmony or a simple harmonic vamp of two chords alternating at a measure apiece. These compositions allowed Coltrane to further explore improvising without a predetermined cyclical formal structure. Despite the absence of predetermined detailed formal and harmonic structure, and the dominance of groove-oriented rhythm section playing, the themes underlying Coltrane's musical development from the beginning are still present. Coltrane continues to sonically ground his melodic material in pentatonic scale material and explicit chord tone usage.

Both Porter and Demsey highlight the unique nature of the melody, "Miles' Mode," from this album and the fact that it is based on a twelve-tone row. ${ }^{60}$ Coltrane's solo on this composition deserves mention as well. While Porter is correct in stating that Coltrane "used a mode while improvising" ${ }^{61}$ for the majority of his solo, he does employ his tri-tonic chord substitution over the minor modal rhythmic accompaniment three times during his solo. ${ }^{62}$ Saxophonist Eric Alexander found this technique "mind-blowing," when he was studying Coltrane's playing in college. To Alexander, it sounded very "out" but "I finally realized he was just playing "Giant Steps" changes in a minor key." ${ }_{33}^{\text {"Giant }}$ Steps" had originally been designed as a major harmonic substitution; however, Coltrane took his harmonic concept and treated the minor mode he was soloing on, $\mathrm{C}^{\#}$ minor, as if it were $\mathrm{C}^{\#}$ major. ${ }^{64}$ Figure 6 is a section of Coltrane's solo on "Miles Mode." The rhythm section accompanies him on the tonic minor, while he substitutes the chord changes above. In fact, the first and third instances of his use of tri-tonic substitutions on "Miles' Mode" are both strategically placed during what might be described as the turnaround of the improvised bridge, right before the second statement of the theme in both the head in and head out.

${ }^{59}$ John Coltrane, Coltrane, (Impulse! MCA 29011, 1962)

${ }^{60}$ Porter, John Coltrane, 231; and Demsey, John Coltrane Plays, 69

${ }^{61}$ Porter, John Coltrane, 231

62 "Miles' Mode," Coltrane, (Impulse! MCA 29011, 1962)

${ }^{63}$ Eric Alexander, interview by author, 2000.

${ }^{64}$ Coltrane uses the "minor" version of his tri-tonic harmonic progression over the first four bars of "Fifth House" as well. 


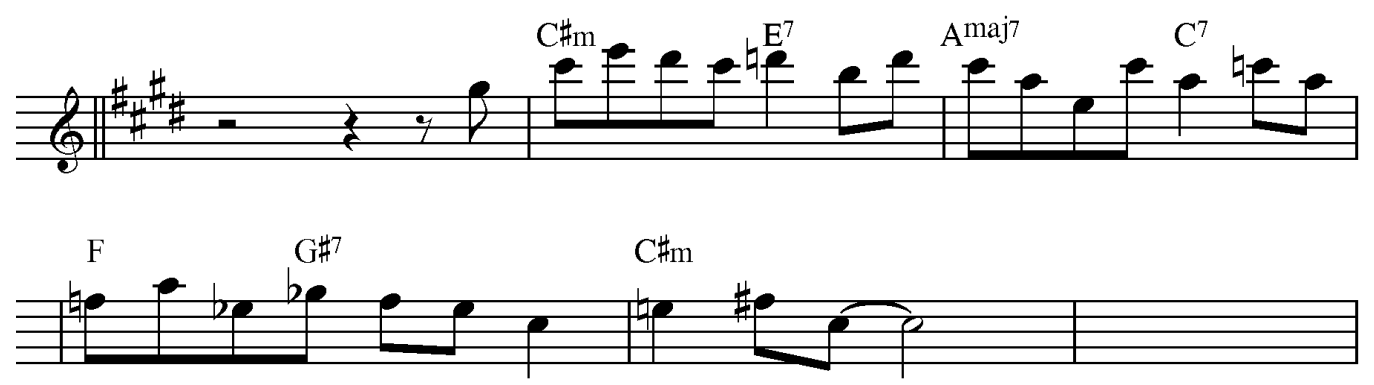

Figure 6. Tri-Tonic Improvisation on "Miles' Mode."

\section{OUT OF THIS WORLD}

Coltrane also used repetitive 4 and 5 note rhythmic patterns as sonic grounding in order to chromatically expand his own implied harmonic structure. As discussed above, Coltrane used pentatonic patterns in an attempt to capture the essence of the harmony of "Giant Steps," providing the most essential elements of the harmony in a compact melodic line. Subsequently, pentatonic patterns became increasingly prominent in his solos. He also used 4 or 5 note repetitive patterns to explore the modal and drone accompaniments his rhythm section was providing for him. He used these repetitive rhythmic patterns to move further away from the harmonic accompaniment. He was able to do this because he performed the repetitive patterns with such rhythmic vigor that they became the sonic grounding that provided a point of reference and mitigated the dissonance created by moving away from the key center. Coltrane uses this technique effectively on his arrangement of Harold Arlen and Johnny Mercer's jazz standard "Out of This World" from the previously mentioned album Coltrane, in a slightly unconventional form. ${ }^{65}$ The five-note groupings he uses in this example are not traditional anhemitonic pentatonic scales, but the fact that he repeats the same five-note rhythmic pattern as he weaves in and out of the harmony, stabilizes his motif and makes the listener's ear accept what he is doing logically. In this example, Coltrane uses the concept that a pentatonic melodic grouping played in any key will sound consonant regardless of what the rhythm section is playing as accompaniment. He takes this concept one step further by disregarding the melodic material and focusing on the repetition of rhythm. Coltrane

65 “Out of this World," Coltrane, (Impulse! MCA 29011, 1962) 
makes evident that the repetition of a rhythmic theme is enough to sonically ground his playing. Thus, although we see a continued use of pentatonic material used in Coltrane's solos to sonically ground his melodic voice-leading and to make clear his implied harmonic progressions, we also see the use of short rhythmic cells repeated with different collections of notes having the same effect. Although it has rhythmic focus, Coltrane's goal and its results remain the same, his implied harmonic progressions, and his voice-leading remain a central focus of his music.

Figure 7 is a selection from Coltrane's solo on "Out Of This World." This example shows his use of five-note repetitive rhythmic groupings as a way to move to substitute harmonies, yet still keeping Coltrane's playing sonically and rhythmically grounded. However, a stronger example of this technique can be found in Coltrane's solo on "Acknowledgment" from his suite, A Love Supreme.
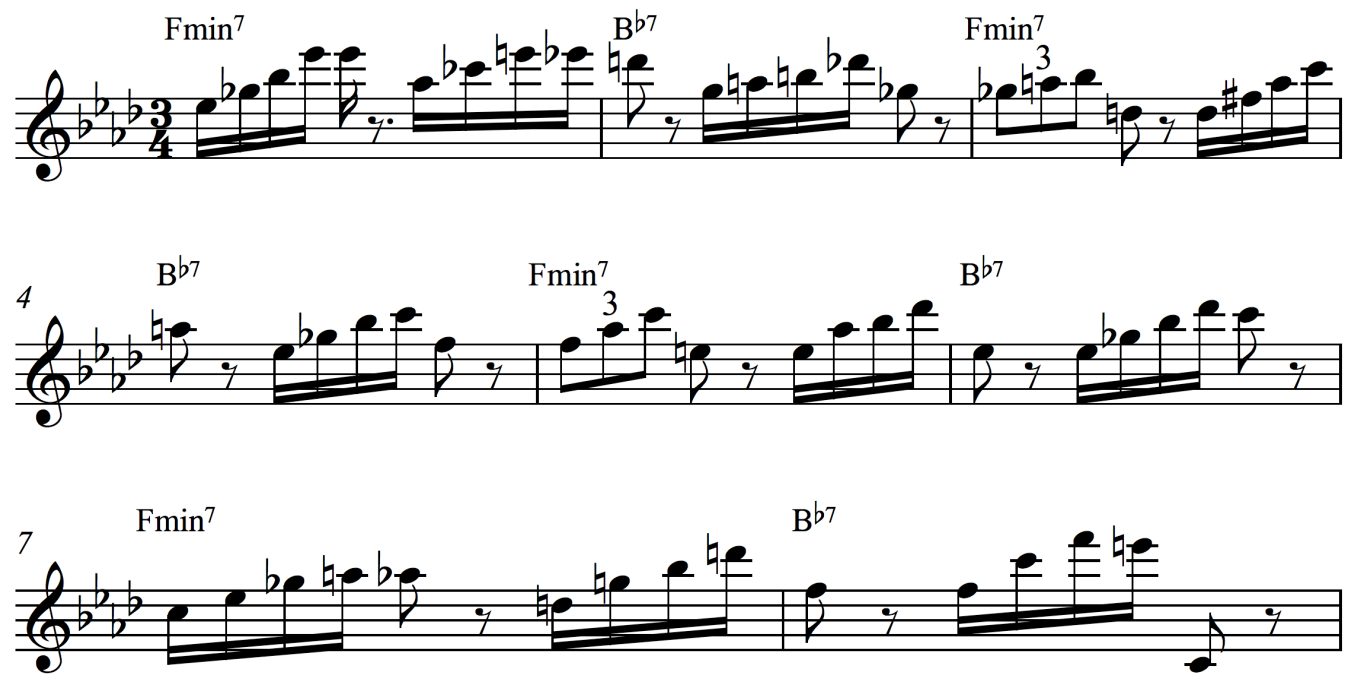

Figure 7. Rhythmic Repetition on "Out of This World"

Coltrane first begins to use repetitive rhythmic figures in earnest around the end of 1961. Porter and Kofsky, both identify Coltrane's growing interest in repetitive rhythms. In an interview with Kofsky Coltrane alludes to the influence of John Gilmore, who used repetitive rhythmic groupings to develop thematic motives in his own solos. ${ }^{66}$ Porter also identifies Coltrane's use of repetitive rhythmic structures, particularly in his later work as primarily thematic. Porter compares Coltrane's use of repetitive rhythmic structures to that of a Western

${ }^{66}$ Frank Kofsky, John Coltrane and the Jazz Revolution of the 1960s, (Pathfinder Press: New York, 1998), 235 
classical composer. Porter states, "This is similar to the way classical composers will write out a motive and its inversions, retrogrades and rotations...but in improvisation one cannot be this methodical." ${ }^{77}$ The results of Coltrane's use of repetitive rhythmic cells at first glance are certainly thematic development. However, when we look deeper into the use of repetitive rhythmic cells in Coltrane's music two things become evident. He uses repetitive rhythmic structures, as a grounding characteristic for his exploration of chromatic modulation. Although Porter states that Coltrane cannot expect to be as methodical as classical composer; I believe there are many instances where he methodically employs repetitive rhythmic structures to a point far beyond what a classical composer might deem necessary. For example, the transposition of the rhythmic theme in "A Love Supreme" and "The Father and The Son and The Holy Ghost," both discussed below are excellent examples of Coltrane's thoroughly methodical treatment of repetitive rhythmic structures. I would like to highlight the affect that using repetitive rhythmic structures has on Coltrane from improvisational standpoint, and the affect repetition has on the listener. In both cases using repetitive rhythms, provides a point of reference, a restricted element of sonic grounding. In the case of the improviser, the repetition provides an element of predetermined stability, something he does not have to think about, allowing the improviser to place most of his concentration on manipulating the harmonic relationship of the melodic material. In the case of the listener, the repetition provides a strong predictable pattern that mitigates the dissonance that occurs from the chromatic transposition of harmonically manipulated melodic material.

\section{A LOVE SUPREME}

Coltrane and his quartet recorded $A$ Love Supreme in $1964 .{ }^{68}$ The album consists of one large programmatic work split up into four sections; Coltrane ties the work together by the use of pentatonic scale material. Coltrane's use of a repeated melodic pattern in the first movement, "Acknowledgement," is most pertinent to our study here because it shows the effectiveness of using a simple repeated rhythmic pattern to mitigate dissonance that occurs by playing out of the established key. The majority of the melodic material used in this movement comes directly from the pentatonic scale, $\mathrm{F} \mathrm{A}^{\mathrm{b}} \mathrm{B}^{\mathrm{b}} \mathrm{C} \mathrm{E}^{\mathrm{b}}$. However, as Coltrane's solo progresses and begins to intensify he develops a repetitive melodic motif to which he eventually sings the words "A Love Supreme."

\footnotetext{
${ }^{67}$ Porter, 1999, 279

${ }^{68}$ John Coltrane, A Love Supreme, (Impulse! 314589 945-2, 1964)
} 


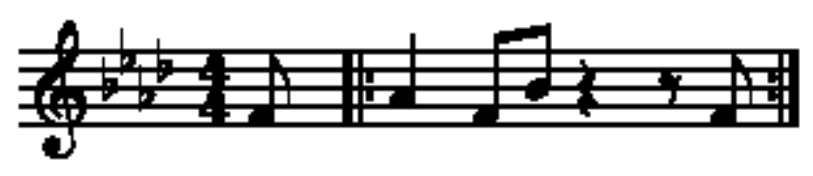

Figure 8. Motif from "Acknowledgement" A Love Supreme

In his perceptive analysis of $A$ Love Supreme, Porter points out that Coltrane uses three techniques to build the intensity of his solo, but at the same time, he limits himself to this motif. "First he intensifies the rhythm, playing it in constantly diminishing note values and with increasing frequency. Second, he uses the range of his instrument, building up to the altissimo register for climaxes...Third Coltrane transposes the motif outside the scale." ${ }^{\prime 9}$ Coltrane transposes this motif to all twelve keys. However, he mitigates the dissonance that occurs at times, due to the transposition, by using a strong repeated rhythm and the sonic grounding of the pentatonic pattern, not to mention the association with the words "A Love Supreme."
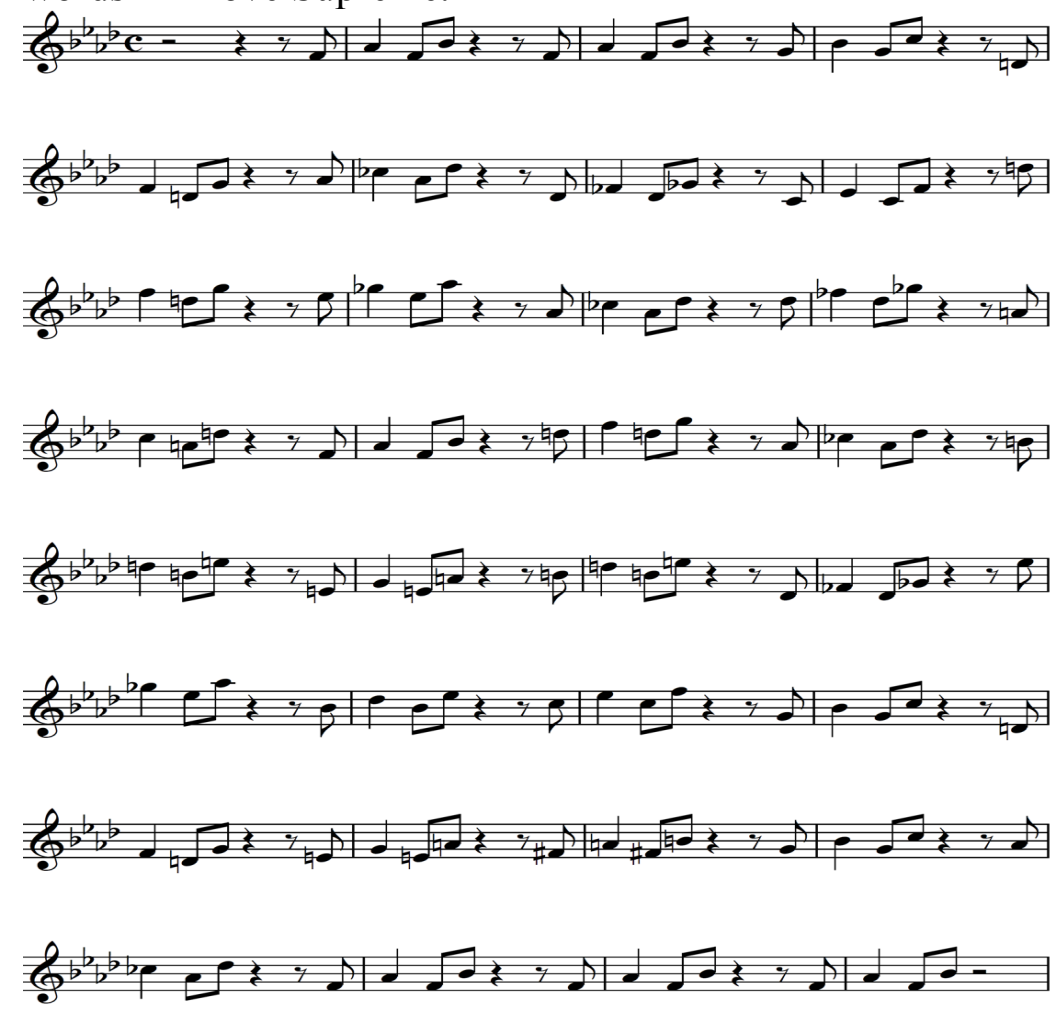

Figure 9. Pentatonic Melodic Development of "Acknowledgement" Motif

${ }^{69}$ Lewis Porter, "John Coltrane's A Love Supreme: Jazz Improvisation as Composition," In Journal of the American Musicological Society, 38:3 (August, 1985), 607. 
Despite what appear to be drastic changes in Coltrane's performance style, almost five years after the recording of "Giant Steps" Coltrane's improvised solo lines still show signs of his conscious effort to explore harmonic progression through sonic grounding with the use of concise melodic voice-leading and strong melodic pentatonic material. In his research on Coltrane, Jeff Bair states that,

What started for [Coltrane] as a means for mastering difficult chord progressions and chord substitutions in his own compositions and those of standard jazz repertoire becomes one of the solutions that provided direction for improvisation over compositions with modal or free structures. The experiment that began with the compositions "Countdown" and "Giant Steps" in 1959 that used major thirds cycles as chord structures can effectively be traced to melodic vocabulary in the improvisations of some of his last recordings in February of $1967 .^{70}$

Discarding the use of dense chords in the rhythm section but keeping them in his solos reinforces the concept that Coltrane endeavored to overcome the restrictive nature of the structural elements of traditional jazz by internalizing harmonic and formal structure. As a result, one might view Coltrane's performances on "Giant Steps" and "Countdown" as a pivot point in his development, with his earlier work leading up to these performances, and the changes in his later musical development directly influenced by them.

BRAZILIA

The album The John Coltrane Quartet Plays, recorded and released directly after his well-received $A$ Love Supreme, posed considerable challenges to many of his listeners. Dave Liebman states that when the recording was first released it was "a big challenge to understand" even for the most dedicated of Coltrane fans. ${ }^{71}$ We can compare the performance of "Brazilia," released on the abovementioned The John Coltrane Quartet Plays album, with two other recordings to gain important insights into why this recording was a challenge to Coltrane's listeners while also developing some strategies to overcome those challenges. The first comparison is to "Acknowledgement," the second comparison is to an earlier

\footnotetext{
${ }^{70}$ Jeff Bair "Cyclic Patterns in John Coltrane's Melodic Vocabulary as influenced By Nocolas Slonimsky's Thesaurus of Scales and Melodic Patterns: An Analysis of Selected improvisations" (Doctoral Dissertation, University of North Texas, August 2003), 56

${ }^{71}$ David Liebman, "John Coltrane's Meditations Suite: A Study in Symmetry." (Annual Review of Jazz Studies 8 (1996): 167 -180) 179
} 
live recording of "Brazilia" recorded at the Village Vanguard in November 1961. The comparison between "Acknowledgment" and "Brazilia" is useful because the two performances have many similar characteristics and Coltrane performed them within a short time of each other; yet, the reception of the two performances was quite different. The comparison between the two versions of "Brazilia" is useful in exploring how the group's performance on this composition changed over the three-year span between their recordings.

I think it is important to recognize the practical aspects of Coltrane's use of pentatonic patterns in his latest works. His use of pentatonic material functions as a grounding agent within the context of the chaos surrounding it. It is not by chance that Coltrane retains much of his harmonically grounded, pentatonic melodic material and repetitive rhythmic structures while the rest of the ensemble is allowed to play in a free manner with less connection to what Coltrane was playing. "Acknowledgement" and "Brazilia" very are two very similar arrangements. They both begin with a rubato introduction; in the case of "Acknowledgement," it is a short improvised flourish while the introduction of "Brazilia" is a longer rubato statement of a pre-composed melody. ${ }^{72}$ After the rubato introductions, both performances lead into medium tempo rhythmic groove with an open form in minor tonality. "Acknowledgement" is Latin-infused jazz with a straighter eighth note feel, while "Brazilia" is a medium swing. The differences between the two performances reside in elements of sonic grounding and points of reference. These differences help us to understand why "Acknowledgement" is more accessible to listening audiences than "Brazilia." The rubato introduction to "Acknowledgment" is short, Coltrane improvises in a single tonality. Tyner, who provides a full sonorous harmonic pallet for Coltrane's improvisation, enforces this tonality. Jones also plays on the introduction, but limits his accompaniment to flourishes of cymbal rolls. The introduction of "Brazilia is more than twice as long, the pre-composed melody is chromatic, with strong dodecaphonic elements. ${ }^{73}$ Tyner does not play at all on the introduction and Jones plays primarily on snare and bass drum, which provides a much starker accompaniment. From the very beginning Coltrane removes the sonic grounding; obvious tonality, and harmonic accompaniment, along with the fullness of the cymbal rolls, which all acted as points of reference for the audience on "Acknowledgement."

Both compositions move into strong medium-tempo rhythmic accompaniment. However, Garrison establishes time in "Acknowledgement" with a strong

${ }^{72}$ There is evidence that suggests that composition credit for "Brazilia" should go to Eric Dolphy and not Coltrane. See Dan Voss, "Who Wrote "Brasilia," 2013

http://uebergreifen.blogspot.com/2013/04/who-wrote-brasilia.html

${ }^{73}$ Voss, "Who Wrote "Brasilia," 
repeated ostinato bass groove that firmly sounds the tonic minor vamp in the listeners consciousness. "Brazilia" features no such repetition; from the outset, Garrison's bass line is a moving melodic feature of the performance that only suggests the minor tonality. In both performances Tyner's harmonic accompaniment is forceful, moves chromatically in and out of tonality and features quartal voicings. However, the chromatic motion of the harmony is mitigated on "Acknowledgment" due to the persistence of the sonic grounding provided by the bass ostinato. On "Brazilia" the chromatic nature of the piano voicings is emphasized by the capricious melodic/linear nature of Garrison's bass line. It is interesting to note that Garrison does not strictly perform the repeated ostinato throughout the whole performance of "Acknowledgement" but he plays it enough that when he does move away from the groove and plays melodic bass lines, the listener continues to supply the ostinato subconsciously.

Coltrane's own playing on "Acknowledgement" as discussed above is sonically grounded in two primary elements, the use of pentatonic scales and the repetition of a strong rhythmic motive associated with the words "A Love Supreme." These elements of sonic grounding allow him to move in and out of tonality, and to explore disparate tonalities while still providing points of reference for the listener. These elements of sonic grounding are absent from his performance of "Brazilia." In this instance Coltrane does not rely on pentatonic melodic fragments to aid his harmonic exploration, likewise he has also found rhythmic freedom with the escape from the repetition of rhythmic themes. There are still elements that Coltrane is using to sonically ground his playing, however they have become much more abstract, and more challenging for the listener to relate to. As Schott states:

Giant Steps is an extreme point in Coltrane's development...But the idea of interlocking diatonic or pentatonic figures to achieve chromatic circulation remained a hallmark of his late style, even as he abandoned the chord changes that had generated them. These ideas inform much of his late music, and in his solos they often appear in the midst of wild, virtually non-pitched, overblown textures, where they have the effect of a fervent testimony summoned up by sheer force of will to dispel the surrounding chaos. ${ }^{74}$

A comparison between the two performances of "Brazilia" made approximately three years apart will further show that the performance traits of "Brazilia" in 1965 are not distinct to the composition itself but a direction the group was

${ }^{74}$ Schott, $356-357$ 
moving in as they continued to master and overcome the restrictive nature of the structural elements of jazz improvisation. First, the arrangement and format of the two performances are strikingly similar despite the interval of time between the two recordings. Both performances begin and end with a rubato statement of the melody and improvised solos in steady medium swing. The differences in the arrangement are due to the musicians performing with Coltrane as much as the way that Coltrane himself performs. For example, on the introduction to the 1961 version Coltrane and Dolphy both perform the rubato melody in unison, and the bassist, joins drums in providing improvised support. ${ }^{75}$ The last statement of the melody on the live version is a directed occurrence because it follows the bass solo, which allows the horns to coordinate their entrance. Again, it includes alto, bass and drums, along with Coltrane. The head out on the '65 studio recording is incorporated directly into the end of Coltrane's own improvised solo. Thus, while Coltrane phrases the melody freely the rhythm section supports him with metered rhythmic time until they also break down into free rhythm.

Although Liebman marks the studio recording for its free and chromatic performance by all the members of the ensemble, a few characteristics make the 1961 recording more avant-garde. The addition of the bass on the rubato introduction creates a collective improvised soundscape when compared to the tenor-drums duet of the studio recording, which focuses more of the listener's attention on the statement of the melody. Dolphy's solo on the live recording is certainly as chromatically adventurous as either of Coltrane's solos-'61 or '65and in some ways more so due to Dolphy's penchant for intervallic/angular phrasing. When you compare Dolphy's phrasing to Coltrane's smoother linear phrases the angularity of Dolphy's line provides less continuity and sonic grounding then Coltrane's fluid linear approach. Thus, although one could argue that Coltrane utilizes as much or more chromaticism as Dolphy does, Dolphy's angular phrases make the chromaticism appear more foreign than Coltrane's playing.

In other ways the 1965 studio recording contains elements that provide a feeling of greater harmonic and formal structural freedom. For example, while Reggie Workman's bass line on the 1961 live recording is at times melodic, linear, and chromatic, he often falls into the routine of tonicizing $\mathrm{Eb}$ minor. Furthermore, he clearly moves to the IV chord (Ab) and back again often enough to imply structured harmony that Coltrane often responds to in his

${ }^{75}$ The inclusion of Dolphy on both the in and out head in this case may be do to the fact that this is Dolphy's composition as Voss suggests, see:

http://uebergreifen.blogspot.com/2013/04/who-wrote-brasilia.html 
improvised, blues inflected, solo. The first instance where Workman moves convincingly to the IV chord is at the 1:50 mark. He moves though the IV chord again briefly at about 2:30 and then pedals on IV (Low $\mathrm{Ab}$ ) consistently for a full eight measures beginning at 3:26 before moving back to the tonic $\mathrm{Eb}$ minor. Workman continues in similar fashion for the duration Coltrane's solo occasionally pedaling on the $\mathrm{Eb}$, and again on the $\mathrm{Ab}$. The strongest instances of tonicization are the above-mentioned 1:50, 3:26, (both $\mathrm{Ab}$,) at 4:04 (Eb) and 5:42 (Ab again). Again, these instances provide structural points of reference for Coltrane who responds to them with elements of blues inflection. They also give the aural appearance of harmonic structure to the listener. The sounding of the subdominant chord and the frequent use of pedal points on the tonic provide sonic grounding for Coltrane to refer to in his solos and it also provides a point of reference for the audience. However, these structural features in the bass line also restrict Coltrane's solo. Coltrane seems compelled to refer to them.

When you compare Workman's bass lines on the live recording to Garrison's bass lines on the studio performance, the feeling of harmonic freedom and lack of perceived structure become much more evident. Garrison avoids implying tonality, the strong motion to and from the sub-dominant $(\mathrm{Ab})$ in two ways. First throughout the duration of the song, he never pedals on any tone; he gives equal weight to virtually every note he plays. He doesn't avoid the Ab, in fact he plays it as often if not more often than Workman but he incorporates the Ab from the very beginning into the linear flow of his bass lines. He never draws attention to the $\mathrm{Ab}$ because it is ever present in his bass lines. As a result, Garrison's bass lines remain consistently melodic, utilizing linear, stepwise and chromatic motion throughout. He resists pedaling on any single note that might suggest a stable tonality, and subsequently does not suggest a move away from the tonic to subdominant that we hear from Workman in the live recording. As a result, the performance lacks the perception of harmonic structure that underpins the live recording. I believe this is the intended, desired affect of the performance. The overall harmonic soundscape is more open and free, Coltrane responds to this freedom by performing in kind, with an improvised solo that is equally harmonically and rhythmically unrestricted.

Tyner's accompaniment on both Coltrane's and Dolphy's solos of the live performance, hovers closely to the minor tonality. Tyner's comping on the studio version shows an increase in chromaticism, and more confidence in moving fluidly in and out of tonality. Tyner's confidence in the studio is equally on display in his forceful and strident solo, he does not solo on the live recording. We hear in the studio recording a rhythm section that has acquired the harmonic and rhythmic mastery to accompany Coltrane in a very liberating way not present on the live recording. The sonic grounding provided by the bass and piano on 
the live recording are no longer present in the studio recording. As a result, Coltrane has less structural restrictions to refer to in his solo, it has a freer characteristic both harmonically and formally. However, the audience also has less to hold onto. There are less structural points of reference for them. Thus the change occurring in the performance of "Brazilia" is in the confidence and mastery that the rhythm section performs with as much as Coltrane's own solo efforts.

Assessing Coltrane's performance directly one might argue that he employs more tonal/textural expressive elements in his live recording while remaining closer to the harmonic structure suggested by the bass line. In the studio recording he restrains his tonal/textural expressions opting to focus more on exploring remotely connected harmonic relationships through his chromatic note choices. The rate of intensity and speed at which he develops his ideas is extremely quick. However, if one is able to hear beyond the freer playing in the rhythm section, Coltrane remains deliberate with the voice leading of his melodic lines as he makes explicitly clear the harmonic progressions he is implying. Bair sums up this point nicely stating, "The significant difference here is that the [harmonic] cycle implied by Coltrane on "Brazilia" is not played by the rhythm section in the accompaniment, while the Coltrane compositions from 1959 and 1960 include the thirds cycles as accompanying chord progressions." 76

\section{THE FATHER THE SON AND THE HOLY GHOST}

Meditations suite is another strong example of Coltrane's use of sonically grounded melodic lines. With this collection of freely-improvised compositions, Coltrane displays elements of melodic and rhythmic sonic grounding by restricting his note choices to simple major scale and pentatonic note collections at the statement of each melody. He uses repetitive rhythmic structures as a way to develop freely improvised solos. Liebman presents an analysis of the use of pentatonic melodic lines in his article "John Coltrane's Meditations Suite: A Study in Symmetry." Liebman states, "By and large the melodies are extremely diatonic, while the harmonies played by the bass and piano are non-tonal, as are the improvisations... The Motif itself is unyielding and in its shape presents what must be the clearest example of tonality and melody in all music-the 1,2,3,5 of the major key!" ${ }^{\prime 7}$ Once again, we see Liebman identify Coltrane's use of sonic grounding: expressing a clear example of tonality and melody through his melodic lines. Into his latest years Coltrane retained essential melodic content

\footnotetext{
${ }^{76}$ Bair, 36

${ }^{77}$ Liebman, 169
} 
in the form of the pentatonic melodic groupings he was practicing in the early 1950's as identified by both Porter and Heath. Speaking of the same suite, Schott states, "the typical Coltrane motif is pentatonic, three to five notes, rhythmically square, and unpromising in its potential for development." ${ }^{78} \mathrm{He}$ continues by stating: "As with Giant Steps, there is a suggestion of eternity in these cyclical modulations, one feels that a process is going on that began before the music started, and doesn't end so much as drift off, or dissolve into something else." 79

Coltrane also uses repeated rhythmic cells in almost every movement of the suite. The one exception is "Compassion," which appears to be free rhythmic improvisation. If we compare some of the material in the first movement "The Father and The Son and The Holy Ghost," ${ }^{\prime 0}$ to the well received first movement of $A$ Love Supreme we can make some connections that provide points of reference that might be obscured in Meditations Suite initially. The rhythmic theme of the melody fits the rhythmic pattern of the title.

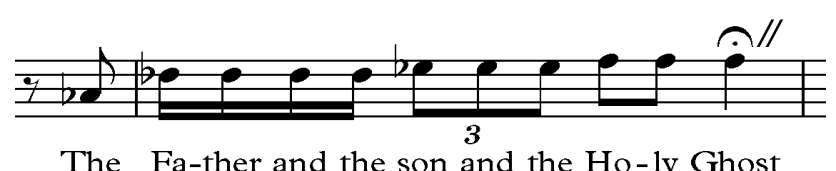

The Fa-ther and the son and the Ho-ly Ghost

Figure 10. "The Father the Son and the Holy Ghost," Rhythmic pattern of the title.

While Coltrane transposes the rhythmic theme of "A Love Supreme" within the development of his improvised solo, he uses this same developmental technique in the pre-composed statement of the melody on "The Father...". ${ }^{81}$ The development of the "Love Supreme" theme acts as a climax of the first movement. The cyclical transposition of "The Father..." is a starting point for more intense tonal/textural improvisation. Coltrane manipulates the rhythmic theme of "The Father..." with his customary common-tone voice-leading, and uses a combination of two cycles to develop his melody. Coltrane transposes the rhythmic theme either up a perfect fourth, or down a minor third. Every time he moves up a perfect fourth, his rhythmic theme ends on the root of the present chord, which then acts as the fifth, the pick up note to the next theme. When Coltrane moves down a minor third, his rhythmic theme ends on the major third, which becomes the fifth, the pick up note of the next theme. He keeps this

\footnotetext{
${ }^{78}$ Schott, 357

${ }^{79}$ Ibid, 362

${ }^{80}$ Hereafter referred to as "The Father..."

${ }^{81}$ Liebman suggests in his article that Coltrane pre-composed the melody. (Liebman, 169.)
} 
common tone modulation consistent throughout. The consistency of the rhythmic theme, along with the common-tone modulation allows him to transpose the initial theme to distant key centers in the same way that he manipulates the theme of $A$ Love Supreme.
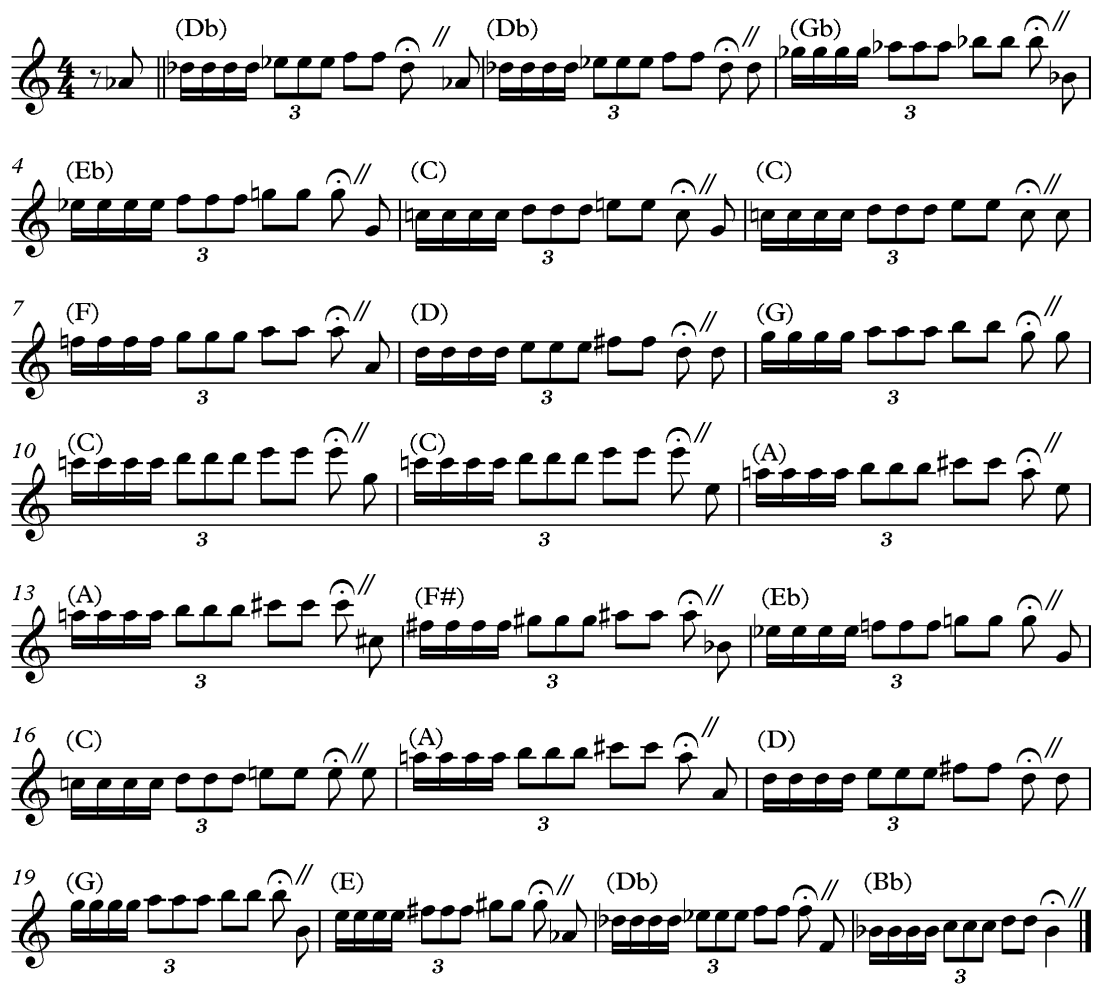

Figure 11. "The Father the Son and the Holy Ghost" melody.

Like "Acknowledgement," and "Brazilia," "The Father..." begins with a rubato introduction, and yet again, we see that Coltrane has minimized or removed any point of reference the listener identified with in "Acknowledgement." Pharaoh Sanders improvises alongside Coltrane this time, and both tenors explore sound textures including vocal screams, multiphonics, tonal shakes, and harmonic overtones. Jones and Rasheed Ali, collaborate to provide a tapestry of cymbal sounds and lower tom drum rolls and accents that accompany the saxophonists. Bass and piano also improvise freely during the introduction providing a non-functional harmonic pallet. In short, the introduction to "Acknowledgement" has concise direction and a conclusion the listener can expect and anticipate. It has relatable structure to it that provides a point of reference for the listener. The opening of "The Father..." is atmospheric; it seems to suspend time and direction. The relatable structural elements of tonality 
and time are present only in their vaguest forms. In his improvised solos, Coltrane seems most occupied with the development of pentatonic thematic material in "Acknowledgement," the focus of "The Father And The Son..." certainly is textural expressions idiomatic to the tenor saxophone. In this performance, Coltrane has minimized the prescribed structural elements of harmony and form. Because of the internalization of harmony and form, metered time is also becoming a restrictive hindrance rather than a helpful point of reference for Coltrane. We see than in his final recordings he attempts to minimize the structural element of metered time in the same manner that he eschews harmonic and formal structure, in the end he internalized all three structural elements and implements them at will.

\section{OFFERING}

Liebman, Schott, and Bair, all make important contributions to understanding Coltrane's last years of music by showing direct connections between his avant-garde free playing and his use of tri-tonic major third relationships, of his "Giant Steps" chord progressions. There are further connections between Coltrane's last works and what he was doing in the 1950s. As mentioned above, while performing with Davis and Monk, Coltrane concentrated on using upper extensions and chord substitutions. He performed these chords while the rhythm section continued to provide the standard accompaniment. Thus, a large degree of the music was dissonant due to Coltrane playing out of the key. We see here in Coltrane's late works a similar effect. Coltrane chose very deliberate harmonic structures and melodic pathways through his music. This time, the dissonance is created because the rhythm section is allowed to play freely around him. However, from a larger picture the effect is very similar. Both Schott and Ekkehard Jost connect Coltrane's improvisation style from 1965-1967 to the way Coltrane played in the late 1950s, the first time he was traveling through equilibrium towards an apex of the pendulum. Jost suggests Coltrane's vast melodic runs of the late 1960s are an even better example of "sheets of sound" then his melodic lines in the late 1950s. ${ }^{82}$ Schott states, "Coltrane's regard for linear voice-leading, which he had honed in the 'chord-on-chord' studies of the late fifties, is here remade, carefully filling out not just the complete chromatic, but almost every note on the instrument." 83

Coltrane's son Ravi Coltrane, who has studied his father's playing extensively has said, "I hear Giant Steps in many of his 1965-1966 recordings. In many of

${ }^{82}$ Quoted in Porter, 279

${ }^{83}$ Schott, 364 
his solos he used that progression in major thirds with the idea of dominants setting up a resolve." ${ }^{84}$ One of the musicians who performed with Coltrane, during his last years, Archie Shepp, echoes Ravi Coltrane's statement, saying that "even when playing free, [Coltrane] liked to be able to refer to harmonies he was familiar with." ${ }^{85}$ One may wonder why Coltrane continued to retain his interest in harmonic progressions and melodic voice leading even as he encouraged his rhythm section to play ever freer. Schott offers a reasonable explanation as to why Coltrane needed to retain something structurally in his playing, "Even after Coltrane largely abandoned functional harmony in his work, he satisfied his need of organization by deriving many of his improvisational ideas from intervallic patterns and synthetic scales." ${ }^{86}$ Speaking specifically of two very late recordings by Coltrane, "Expression" and "Offering," Schott states "The basic units here, as in all of Coltrane's work, are pentatonic and whole tone scales, used complete or in part, and chromatically interwoven." ${ }^{87}$

What I find most interesting in Coltrane's last recordings is not his use of tritonic major third relationships, but the diminishing of pre-composed structural elements common in traditional jazz improvisation. He continues to develop his skills at constructing these structural elements through his improvisation, thus retaining structure and minimizing its restrictiveness. Even in the midst of what at first glance appears to be free-form, chaotic, avant-garde improvisation, Coltrane is still improvising over musical structures that underpin all jazz improvisation; harmonic progression, metered time and cyclical form. However, he employs these features at his own discretion. All three are present, yet extremely fluid and subject to change at any time. Two separate performances of "Offering" provide an excellent example of the improvised structural elements found in Coltrane's latest performances.

Compare two versions of "Offering;" the first, a live version performed at Temple University, November 11, 1966, and the second, a studio recording made in March 1967.

\footnotetext{
${ }^{84}$ Ravi Coltrane, Quoted in Shipton, New History of Jazz, 753

${ }^{85}$ Archie Shepp, Quoted, Ibid, 753

${ }^{86}$ Schott, 173

${ }^{87}$ Ibid, 364
} 


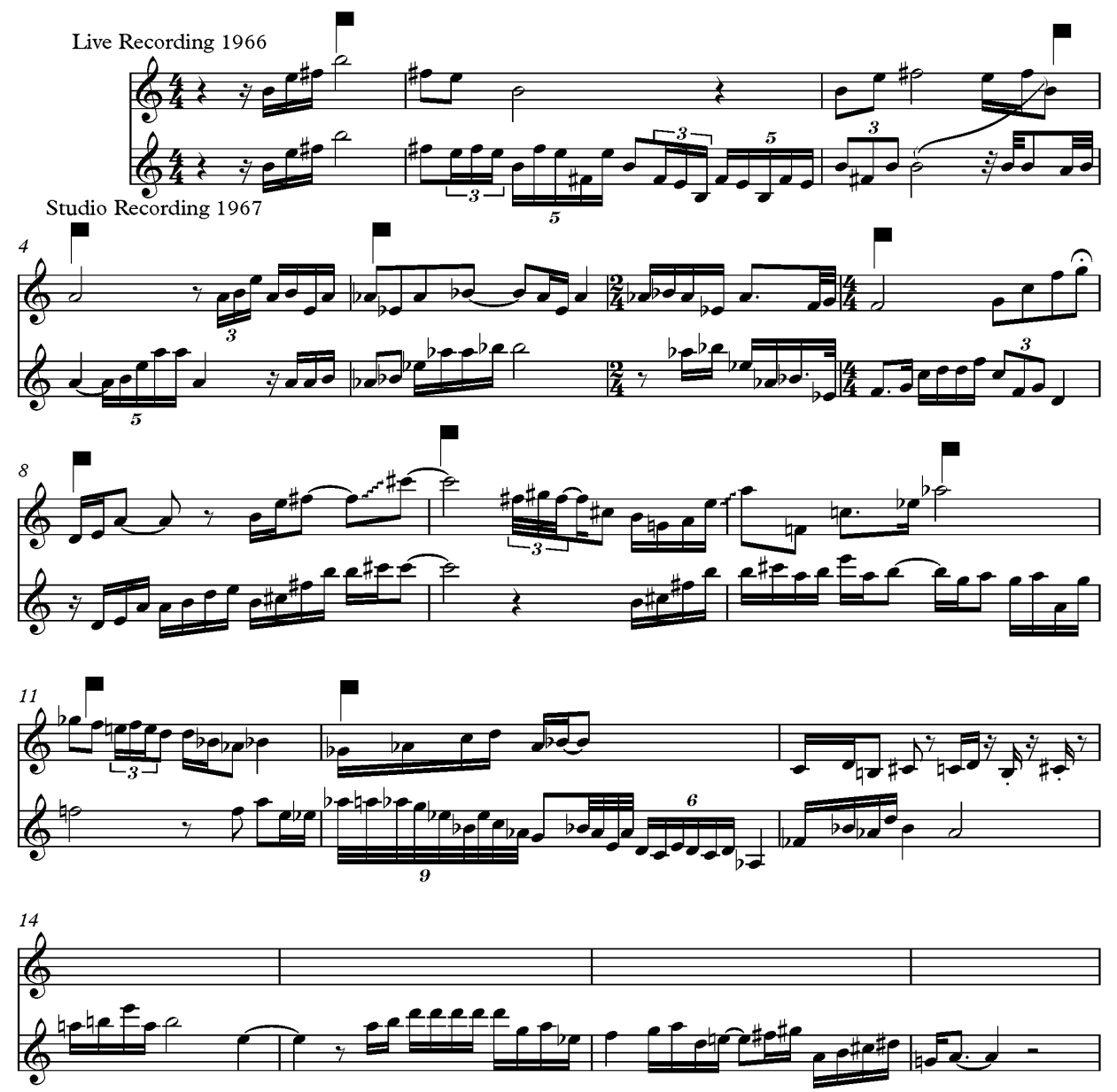

Figure 12. Two Versions of "Offering."

One can see that the initial statement of the melody is very improvisatory, yet at the same time there are distinct structural elements that Coltrane maintains in each performance. He uses a descending melodic line of target notes from which he embellishes melodic lines moving from one target note to the next. I have identified these melodic target notes with flags on the transcription. If we were to examine the melodic statement reduced to the target notes we could reduce both performances to the following series of notes.

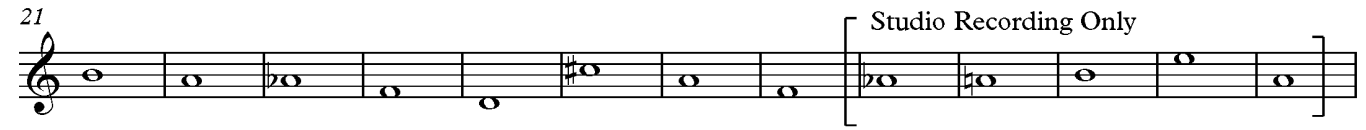

Figure 13. Offering melodic reduction. 
To my ears the live recording is a preparation or practice for the more extensive performance made in the recording studio in March. I say this for a few reasons; first, Coltrane's statement of the initial melody has the feeling of hesitation to it, perhaps an air of becoming comfortable. The improvised lines moving from one target note to the next are relatively simple, less fluid, and embellished. Second, Coltrane appears to explore a distinctive structural nature to the solo section in the live performance, which he develops extensively in the studio recording. Coltrane alternates his improvisation between sections of lyrical flowing melodic lines and staccato accented bursts of repeated 4-5 note rhythmic cells. In both performances, Coltrane uses very similar repetitions of this rhythmic cell, giving further evidence that it was a structural element of the song designed to be developed during improvisation.

Live Version 1966

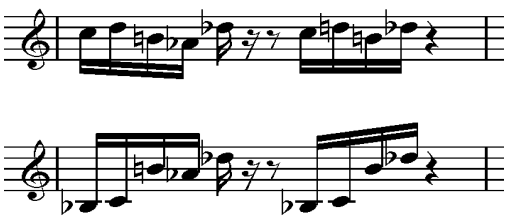

Studio Version 1967

Figure 14. "Offering" rhythmic reduction.

\section{STELLAR REGIONS AND VENUS}

The studio recordings that Coltrane made in 1967 provide for us an excellent example of Coltrane's final explorations. Coltrane recorded a collection of compositions over a period of two weeks in February. The recordings are of two kinds, the first are recordings of the full group, and the second are a series of duet recordings, tenor and drum set with Ali. The full group recordings are available on the recording Stellar Regions, and the duets on the recording Interstellar Space. Porter provides a transcription and analysis of Coltrane's solo on "Venus," (from Interstellar Space,) that is extremely valuable in understanding how Coltrane focused on using specific musical elements to develop his improvisation. Porter describe "Venus" as profound and moving, and states that "Coltrane has succeeded, precisely because he gave up chord changes, and the restriction of a steady beat, in creating a seamless musical construction, not divisible into choruses." 88 In describing the performance, Porter states, "What seems to be chaotic is just the opposite. Coltrane managed to create long solos that follow seamlessly from theme to improvisation...the improvisations were

${ }^{88}$ Porter, 1999, 288 
devoted relentlessly to the exploration of abstract motivic ideas." 89 To a large degree, I agree with Porter. However, to say that Coltrane gave up chord changes is not entirely accurate. He has given up a pre-determined order of chord changes, opting to employ harmonic progression at will. He has achieved complete structural freedom, but not abandonment of structural elements. Once again, Porter's statement is further indication that Coltrane was concerned with isolating specific musical characteristics. Porter's description of them as abstract motivic ideas is useful and I would add detail to that description by calling them primarily textural music expressions. Porter describes Coltrane's fast flowing lines stating that, "Coltrane is really attempting to create an orchestral effect with these scales." 90 He highlights a single reoccurring note in the melodic line that the listener should hear as the primary melodic element while the rest of the notes act as accompaniment. I would augment this view by suggesting that the flowing lines are not intended to be viewed individually, but as a tapestry of sound in which the individual notes, or their tonality, are not as important as the textural sonic effect created by the collection of pitches sounding so close together. As Porter states, "He seems intent on breaking loose from the monophonic restrictions of his instrument." 91

Theorist and saxophonist, Dan Voss has also analyzed "Venus," and provides a compelling argument for Coltrane's use of three specific tonal centers during the improvised performance. ${ }^{92}$ Voss states,

"Venus" is, broadly speaking, tonal (not however in the Schenkerian
sense of prolongation of a tonic triad) and teleological. The piece begins
with the statement of a theme in the key of C; it leaves the tonic key and
develops; and it returns to the initial theme in the tonic key of C. Within
that structure, "Venus" exhibits a cyclic harmonic form; namely, the ma-
jor third interval cycle that is often associated with Coltrane. Specifically,
the harmonic form of "Venus" comprises the diatonic collection with
root transpositions of C, A b, and E. The cycle mostly descends (C-A b-
E) but also occasionally ascends $(\mathrm{C}-\mathrm{E}-\mathrm{A} b) .$. The music of "Venus" is at
no point "atonal."

I highly recommend Voss's analysis for anyone interested in comprehending the harmonic structural framework improvised in Coltrane's solo. Comparing Coltrane's performances on two versions of the title track "Stellar Regions" with

\footnotetext{
${ }^{89}$ Porter, 1999, 276

${ }^{90}$ Porter 1999, 278

${ }^{91}$ Porter, 1999, 278

${ }^{92}$ Voss “Venus," May 2015. http://uebergreifen.blogspot.com/2015/05/venus.html

${ }^{93} \mathrm{ibid}$.
} 
"Venus" from the duet session, we can once again glimpse the creative exploratory nature of Coltrane's artistic process. "Stellar Regions" and "Venus" share the same melodic theme and for our purposes, they are performances on the same composition. Both versions of "Stellar Regions" are uncharacteristically short. One version is approximately 3:30 and the other is 4:40. Although they are group performances, Coltrane is the only one to solo, the rhythm section acts as accompaniment only. Music Example 16 is a transcription of Coltrane's solo on 3:30 version of "Stellar Region" I have identified the tonal centers of the solo, and it is clear that Coltrane restricts his tonal explorations to the same major third interval cycle found on "Venus." The same can be said of the 4:40 version of "Stellar Regions" as well. Therefore, we can safely say that this major third interval cycle is an intentional harmonic structural element pertinent to the composition. Looking at the overarching level of intensity in the two performances of "Stellar Regions" it is striking how similar the two are, and how well Coltrane is able to balanced the build-up and resolution the climactic intensity. In both instances, Coltrane is able to build to a climax using the upper regions of his altissimo register at almost the exact midpoint of each performance. With each performance, Coltrane begins his solo in the tenor's lowest register, consistently building to its highest notes and declining back to the lowest register again.

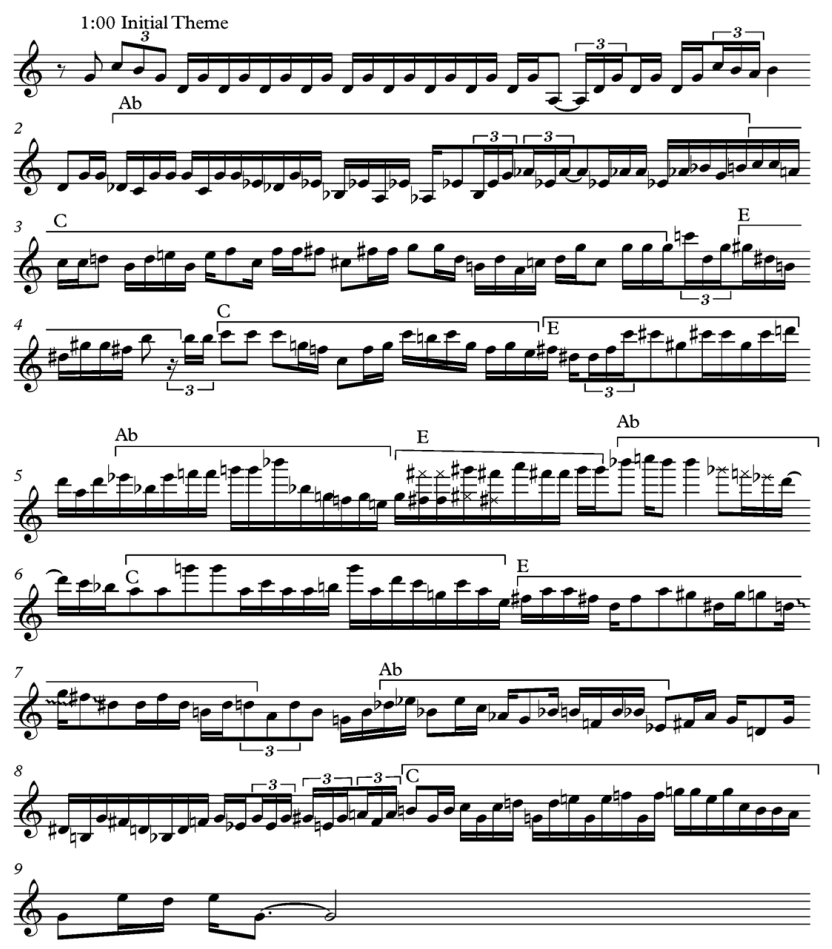

Figure 15. Stellar Regions Solo with tonal centers. 
Both versions of "Stellar Regions" present prime examples of balanced succinct improvised solos. I ask the same question now that I asked in comparing the variations of his "Giant Steps" solos. Why does Coltrane choose to re-record his performance, "Venus," with a different format and produce such a distinctly different performance? Coltrane's performance of "Venus" just a week later is 8:17 approximately twice as long as the two earlier versions and consists of substantially greater development. By performing "Venus" in duet with Ali's non-metrical, textural drumming, we see that Coltrane has finally internalized all three structural elements and eliminated any prescriptive restrictions to the performance. Without the hindrance of the piano and bass, he has more freedom to explore the structural parameters of his improvised performance to a greater degree and with more detail. Both of which are evident from the analysis provided by Porter and Voss. What we gain from the comparison between the performances of "Stellar Region" and "Venus" is an understanding that the "Stellar Region" recordings were precursors, practice runs leading up to the masterful performance of "Venus." Coltrane establishes the structural elements of the composition before their performance, yet at the same time, they exist in such a fashion that they were completely fluid. Coltrane is able to manipulate them at his discretion.

\section{CONCLUSIONS}

It is often easiest to view such a complicated subject as the musical development of John Coltrane segmented up into smaller parts. This allows us to focus on specific traits or building blocks as a way to better understand Coltrane's music. ${ }^{94}$ However, it is important to use the building blocks we examine to see the larger picture: Coltrane's fluid and continuously connected musical output. I view this continuum through Coltrane's steady and continuous pursuit to master and overcome three pre-composed structural elements common to traditional jazz improvisation: harmonic progression, metered time, and cyclical form. All prescribed musical elements are limiting but particularly repeated structural elements like the cyclical elements of harmony, form, and meter found in traditional jazz improvisation. Coltrane acquires his most enduring influence from his mastery of bebop and the music of Charlie Parker, Colman Hawkins, and Dizzy Gillespie. From these influences, Coltrane acquired a deep interest in harmonic progressions that shaped much of the music he created for the rest of his life. Coltrane's desire for freedom of standard harmonic jazz progression and

${ }^{94}$ Baker (1980), Coan (1995), and Schiff (200) each do this in their works on Coltrane, as do Nisenson (1993), Lavezzoli (2007), and Kernfeld (2014). 
his exploratory nature led him to develop a variety of different harmonic progressions eventually culminating in a very symmetric and cyclical progression in major thirds that became the foundation of his later music. This development culminates in the recordings of "Giant Steps" and "Countdown." Coltrane's desire to internalize harmonic structure leads to his use of repetitive rhythmic cells and open-ended, non-cyclical formal structures. His development of smooth melodic voice-leading prompted Coltrane to continually refine his melodic phrasing to eventually focus on the most essential elements of tonality, most often represented by pentatonic scale fragments.

As artistic works, Coltrane's music after $A$ Love Supreme steadily decreases any points of reference for which the listener can rely upon. More so than any other recordings, these works require a number of repeated listening to become familiar with and an understanding of the implied or internalized structural elements. Theses performances distinguish themselves from traditional jazz improvised performances in that, the listener can rely upon previous experience to provide anticipated points of reference in harmonic progression, metered time and cyclical form of traditional jazz performances. These three structural elements are present in Coltrane's late works but the rate and degree of the three structural elements are being determined at the will of the improviser. When Coltrane improvises with the whole rhythm section, we experience a large degree of dissonance due to the discrepancies between Coltrane's improvised performance of structural elements and the rhythm section ability to identify, follow and perform within Coltrane's improvised structural parameters.

Coltrane was a leading avant-garde musician in jazz, but where many of his contemporaries abandoned the restrictive structural elements of jazz (diatonic harmonic structure and metered rhythmic time) Coltrane found his own freedom in mastering and internalizing these restrictive elements. The essence of freedom in Coltrane's music is the ability to apply harmonic and rhythmic structural elements at his discretion with seemingly minimal technical limitation. By the end of his career, he is able to employ structural elements at will in the midst of his improvised solos. Because Coltrane stops prescribing structural elements, the accompanying musicians must also improvise the structural elements at their discretion. Thus, we experience a high degree of dissonance, and atonality in the full rhythm section settings. In his final recordings Coltrane removed all points of reference that at one time provided continuity and cohesion to the group aspect of his performances. He does not abandon the structural elements of music but has mastered them to the point that any pre-determined points of reference are a hindrance rather than a help to him. Coltrane finally removes the limits imposed upon him by his rhythm section by performing in the duet with Ali. Rather than perform in chaos with abandonment, Coltrane employs and 
develops structural elements to the highest level in these recordings. The freedom of this music comes from Coltrane employing these structural elements at will. He is still relying on and referring to elements of harmonic progression, metered rhythm, and cyclical form but he is creating these structural elements improvisationally. It is my hope that in considering Coltrane's work from this standpoint, the listener will have a greater understanding of his most challenging performances.

\section{BIBLIOGRAPHY}

Bair, Jeff "Cyclic Patterns in John Coltrane's Melodic Vocabulary as influenced By Nicolas Slonimsky's Thesaurus of Scales and Melodic Patterns: An Anaysis of Selected improvisations" Doctoral Dissertation, University of North Texas, August 2003.

Baker, David. The Jazz Style of John Coltrane: A musical and Historical Perspective. Lebanon, IN: Studio P/R, 1980.

Bergonzi, Jerry. Melodic Structures: Inside Improvisation, Vol.1. West Germany, Advance Music, 1992.

Berliner, Paul F. Thinking in Jazz: The Infinite Art of Improvisation. Chicago; London: University of Chicago Press, 1994.

Coan, Carl. John Coltrane Solos. Milwaukee, WI: Hal Leonard, 1995.

Cole, Bill. John Coltrane. New York: Schirmer Books, 1976.

Demsey, David. "Chromatic Third Relationships in the Music of John Coltrane." Annual Review of Jazz Studies 5 (1991): 145-80.

Demsey, David. John Coltrane Plays Giant Steps. Hal Leonard, 1996.

Kahn, Ashley. Love Supreme: The Story of John Coltrane. New York: Viking, 2002. 
Kernfeld, Barry; et al. "Coltrane." The New Grove Dictionary of Jazz, 2nd ed.. (Grove Music Online. Oxford Music Online. Oxford University Press, accessed March 14, 2014, http://www.oxfordmusiconline.com/subscriber/article/grove/music/J5418 00pg1.)

Kofsky, Frank. "Elvin Jones Part II: Rhythmic Displacement in the Art of Elvin Jones." Journal of Jazz Studies Vol. 4 N2 Spring/Summer 1977

Kofsky, Frank. "Elvin Jones Part III: an Interview with Elvin Jones." Journal of Jazz Studies Vol. 5 N1 Fall/Winter 1978

Kofsky, Frank. John Coltrane and the Jazz Revolution of the 1960s. Pathfinder Press: New York, 1998.

Lavezzoli, Peter. The Dawn of Indian Music in the West. New York: Continuum, 2007.

Liebman, David. "John Coltrane's Meditations Suite: A Study in Symmetry." Annual Review of Jazz Studies 8 (1996): $167-180$

Logan, Wendell. "The Ostinato Idea in Black Improvised Music: A Preliminary Investigation" The Black Perspective in Music Vol. 12, No .2 (Autumn 1984) 193-215

Lyon, Jason. "Coltrane's Substitution Tunes" unpublished article, www.opus28.co.uk/jazzarticles.html

Modirzadeh, Hafez. "Archetypes and Cyclic Perspecitives in the Work of John Coltrane and Ancient Chinese Music Theory." Black Music Research Journal, Vol. 12, No. 1 (Spring, 2001), pp.75-106.

Nisenson, Eric. Ascension: John Coltrane and His Quest. 1st ed. New York: St. Martin's Press, 1993.

Porter, Lewis. "John Coltrane's A Love Supreme: Jazz Improvisation as Composition." In Journal of the American Musicological Society. 38/3: 593-621 August, 1985. 
Porter, Lewis. John Coltrane: His Life and Music. Ann Arbor: University of Michigan Press, 1998.

Priestley, Brian. Coltrane. Great Britain: Apollo Press Limited, 1987.

Schiff, Ronny. Coltrane Plays Standards. Milwaukee: Hal Leonard, 2000

Schott, John. "We Are Revealing a Hand that Will Later Reveal Us: Notes on Form and Harmony in Coltrane's Work" Arcana: Musicians on Music, ed. John Zorn, New York, NY; Hips Road and Granary Books, 2000.

Shipton, Alyn. Groovin' High: The Life of Dizzy Gillespie. Cary, NC, USA: Oxford University Press, USA, 2001.

Shipton, Alyn. New History of Jazz. London; New York: Continuum Press, 2001.

Simpkins, Cuthbert Ormond. Coltrane: A Biography. Baltimore, MD: Black Classic Press, 1989.

Thomas J.C. Chasin' the Trane: The Music and Mystique of John Coltrane. New York: Da Capo Press, 1976.

Voss, Dan. "Who Wrote "Brasilia." http://uebergreifen.blogspot.com/2013/04/who-wrote-brasilia.html

Voss, Dan. "Venus," May 2015. http://uebergreifen.blogspot.com/2015/05/venus.html

Woideck, Carl. Charlie Parker: His Music and Life. Ann Arbor, University of Michigan Press, 1998.

Woideck, Carl. The John Coltrane Companion: Five Decades of Commentary. New York: Schirmer Books, 1998. 


\section{DISCOGRAPHY}

"Just For the Love." September 21, 1956. Whims of Chambers. Blue Note BST 81534.

"Straight Street." September 21, 1956. Whims of Chambers. Blue Note BST 81534.

“Moment's Notice." September 15, 1957. Blue Trane. Blue Notes BST 81577

“Giant Steps (Alternate Take)." March 26, 1959. Alternate Takes. Atlantic SD 1668.

“Giant Steps.” May 5, 1959. Giant Steps. Atlantic SD 1311.

“Countdown." May 5, 1959. Giant Steps. Atlantic SD 1311.

“Fifth House.” December 2, 1959. Coltrane's Jazz Atlantic SD 1354.

"My Favorite Things." October 24, 1960. My Favorite Things. Atlantic SD 1361.

"Brazilia." November 2-3, 1961. The Complete 1961 Live At the Village Vanguard Recordings. Impulse! B000003NA3.

“Miles Mode.” June 20, 1962. Coltrane. Impulse! MCA 29011.

“Out of This World.” June 20, 1962. Coltrane. Impulse! MCA 29011.

“Acknowledgement." December 9, 1964. A Love Supreme. Impulse! 314589 945-2.

“Brazilia." May 17 1965. The John Coltrane Quartet Plays. Impulse! MAC D33110

"The Father and the Son and the Holy Ghost" September 23, 1965. Meditations. Impulse! A 9110. 
“Offering." November 11, 1966. Live At Temple University. Universal Japan 0567265 .

“Stellar Regions.” February 15, 1967. Stellar Regions. Impulse!/GRP 11692.

“Venus.” February 22, 1967. Interstellar Space. Impulse! 5434152.

“Offering.” March 7, 1967. Expression. Impulse!/GRP AAGRD 131.

\section{INTERVIEW}

Alexander, Eric. Interviewed by the author. Tape Recording. May 14, 2000. Scullers Jazz Club, Cambridge, Massachusetts.

\section{ABOUT THE CONTRIBUTOR}

Jason Squinobal is the Director of Instrumental Music at Virginia Wesleyan Univesity, in Norfolk, VA. Squinobal earned his PhD in Ethnomusicology from the University of Pittsburgh. His dissertation entitled, "West African Music in the Music of Art Blakey, Yusef Lateef, and Randy Weston" explores the social and cultural influences that encouraged those three musicians to incorporate elements of West African music into their compositions and jazz performance. Squinobal performs internationally with his own groups and as a freelance musician. Squinobal has performed at The Hartford Jazz Festival, the "Africa Meets North America Music Festival" at UCLA in Los Angeles, the Midwest Music Festival in Chicago and as a guest soloist at Long Lake Camp for the Arts in Long Lake, NY. He has also toured Jamaica and England, and has performed in clubs and jazz venues throughout the United States and Canada. 